\title{
Neuroinflammation and Neurogenesis in Alzheimer's Disease and Potential Therapeutic Approaches
}

\author{
Pi-Shan Sung ${ }^{1,2}$, Po-Yu Lin ${ }^{1}$, Chi-Hung Liu ${ }^{3,4}$, Hui-Chen $\mathrm{Su}^{1}$ and Kuen-Jer Tsai ${ }^{2,5, *(\mathbb{C})}$ \\ 1 Department of Neurology, National Cheng Kung University Hospital, College of Medicine, National Cheng \\ Kung University, Tainan 704, Taiwan; pishansung@gmail.com (P.-S.S.); pylin1991@gmail.com (P.-Y.L.); \\ shjmirage@yahoo.com.tw (H.-C.S.) \\ 2 Institute of Clinical Medicine, College of Medicine, National Cheng Kung University, Tainan 704, Taiwan \\ 3 Department of Neurology, Linkou Chang Gung Memorial Hospital, Taoyuan 333, Taiwan; \\ ivanliu001@cgmh.org.tw \\ 4 College of Medicine, Chang Gung University, Taoyuan 333, Taiwan \\ 5 Research Center of Clinical Medicine, National Cheng Kung University Hospital, College of Medicine, \\ National Cheng Kung University, Tainan 704, Taiwan \\ * Correspondence: kjtsai@mail.ncku.edu.tw; Tel.: +886-6-235-3535-4254
}

Received: 30 December 2019; Accepted: 19 January 2020; Published: 21 January 2020

\begin{abstract}
In adult brain, new neurons are generated throughout adulthood in the subventricular zone and the dentate gyrus; this process is commonly known as adult neurogenesis. The regulation or modulation of adult neurogenesis includes various intrinsic pathways (signal transduction pathway and epigenetic or genetic modulation pathways) or extrinsic pathways (metabolic growth factor modulation, vascular, and immune system pathways). Altered neurogenesis has been identified in Alzheimer's disease (AD), in both human AD brains and AD rodent models. The exact mechanism of the dysregulation of adult neurogenesis in AD has not been completely elucidated. However, neuroinflammation has been demonstrated to alter adult neurogenesis. The presence of various inflammatory components, such as immune cells, cytokines, or chemokines, plays a role in regulating the survival, proliferation, and maturation of neural stem cells. Neuroinflammation has also been considered as a hallmark neuropathological feature of AD. In this review, we summarize current, state-of-the art perspectives on adult neurogenesis, neuroinflammation, and the relationship between these two phenomena in AD. Furthermore, we discuss the potential therapeutic approaches, focusing on the anti-inflammatory and proneurogenic interventions that have been reported in this field.
\end{abstract}

Keywords: Alzheimer's disease; neurogenesis; neuroinflammation

\section{Introduction}

Alzheimer's disease (AD) is the most common neurodegenerative dementia worldwide and is characterized by early impairment of recent memory. As the disease severity progresses, AD patients have extensive symptoms, including impaired language, orientation, and executive functions, which lead to a decline in self-care ability. The two hallmark pathologies of $A D$ are $\beta$-amyloid (A $\beta$ ) deposition and neurofibrillary tangles (NFTs) containing hyperphosphorylated tau (P-tau). A definitive diagnosis of $\mathrm{AD}$ requires an autopsy of brain tissues. However, recent emerging evidence has proposed that biomarkers of cerebrospinal fluid (CSF) $\left(\mathrm{A} \beta_{40}, \mathrm{~A} \beta_{42}\right.$ or its ratio and total tau or hyperphosphorylated tau in CSF) and positron emission tomography (amyloid-PET or tau-PET) combined with clinical criteria could assist in diagnosing living people [1].

The disruption concerning $A \beta$ is the result of an overproduction or reduced clearance [2]. In addition, aging, as well as genetic or environmental factors contribute to the metabolic shift of amyloid 
precursor protein (APP) toward the amyloidogenic processing pathway [3]. A $\beta$ peptides aggregate into insoluble oligomers and protofibrils, further instigating fibrillary $\mathrm{A} \beta$ species and, then, accumulate into senile and neuritic plaques. In addition to overproduction of $A \beta$, a reduction in $A \beta$ clearance from the brain also results in the extracellular accumulation of $A \beta$ and, subsequently, cascades of P-tau deposition, cytoskeletal changes, neuronal dysfunction, and neuronal death develop [4]. However, the physiological function of APP is still unknown and A $\beta$ plaque has been observed 10 years or more before the onset of observable AD symptoms or a diagnosis [5].

Tau protein, a microtubule-associated protein, stabilizes microtubules. While tau protein is abnormally hyperphosphorylated and glycosylated, its biological function is impaired in AD. Abnormal folding of P-tau leads to the generation of paired helical filaments (PHFs) and NFTs, which are additional key neuropathological features of AD [6,7]. PHFs induce intracellular accumulation of tau protein in aggresomes [6] and the release of PHF from neurons into extracellular spaces induces the propagation of tau pathology across the different brain regions in $\mathrm{AD}$ patients [8,9]. The severity of tau accumulation is closely associated with dementia severity and neurodegenerative processes in $\operatorname{AD}[10,11]$.

Although a number of studies have indicated that amyloid deposition and tau proteins are two core neuropathologies responsible for $\mathrm{AD}$, results of clinical trials that modulated these two pathological proteins by means of straightforward amyloid- or tau-immunotherapy were disappointing [12-15]. There is still a considerable gap in our understanding of AD pathogenesis. For example, the brain $A \beta$ level increases in many neurological conditions other than $A D$, such as traumatic brain injury, stroke, multiple sclerosis, amyotrophic lateral sclerosis, and hypoxic ischemic encephalopathy. The mechanism for the increase in the $A \beta$ level is still unclear but it could be a response to a neuronal insult or damage. Thus, in $\mathrm{AD}$, the overproduction or accumulation of $\mathrm{A} \beta$ could be an attempt to repair the initial neuronal injury and maintain normal brain function [16]. The upstream pathophysiological process is neuroinflammation or abnormal microglia activation [17-20]; metabolic failure, regardless of etiology [21]; oxidative stress [20]; or sustained cholesterol-associated neuronal distress [22]. In addition, the recent "stress threshold change of state" model has been proposed to explain the presence of early-onset $\mathrm{AD}$ and late-onset sporadic $\mathrm{AD}$ [23]. To date, a considerable gap regarding the onset and progression of AD neuropathology and clinical symptoms still exists.

Over the last few decades, a third core neuropathological feature of AD has emerged. In addition to $A \beta$ and NFT, neuroinflammation is exhibited in the brains of AD patients $[18,19,24-29]$. Such neuroinflammatory changes in AD have been observed in animal models [30,31], postmortem human brains [32-34], and through molecular imaging to detect inflammatory processes [35,36]. A number of studies have discussed the potential role of microglial genes in the regulation of neuroinflammation and the relationship between microglial genes and late-onset sporadic AD [29,37-41]. This neuroinflammatory process is responsive to neuronal loss or to the presence of pathological protein aggregation in AD. However, a number of studies have also suggested that sustained neuroinflammation is noted in the early disease phase of $\mathrm{AD}$. With the progression of disease, such early inflammation facilitates and exacerbate the generation of $A \beta$ and NFT and further results in neuronal toxicity and death [24,42-45].

Neurogenesis occurs through the division of neural stem cells (NSCs), the maturation of neural progenitor cells (NPCs), and then, migration and maturation into neurons [46]. The process was thought to halt postnatally, but has unexpectedly been detected in adulthood, even throughout the lifetime of the mammalian brain [47]. Adult neurogenesis in the mammalian brain has only been detected in certain limited regions, i.e., the subventricular zone (SVZ) and the subgranular zone (SGZ) of the hippocampus [48]. These regions maintain a neurogenic stem cell niche. Subventricular neurogenesis contributes to olfaction and olfactory neural circuitry [49]. In the SGZ, mature granular cells pass through multiple developmental stages. Stage one (proliferation) is manifested by NSCs, or type 1 radial glial-like cells that express glial fibrillary acidic protein (GFAP), nestin, and sex-determining region Y-box 2 (Sox2). Stage two (differentiation) is represented by intermediate progenitor cells (type 2 cells) that express doublecortin (DCX) or polysialylated neural cell adhesion molecule (PSA-NCAM). Then, 
type 2 cells give rise to stage three (migration) neuroblasts (type 3 cells) or neuronal lineage committed cells that express DCX, PSA-NCAM, and markers for immature neurons (Tuj-1b or NeuroD). Stage four (axonal and dendritic targeting) and stage five (synaptic integration) are manifested by mature neurons that express calretinin, as well as NeuN in stage four and calbindin in stage five, respectively [50]. Adult hippocampal neurogenesis (AHN) plays a crucial role in various hippocampus-dependent functions, including learning and mood [51-54]. Altered or dysregulated adult neurogenesis has been found in various neurodegenerative disorders, such as Parkinson's disease, AD, or Huntington's disease [54-58]. Previous studies have shown that genetic, environmental, and pharmacological factors play a role in regulating AHN [46,55]. Inflammation, either the systemic inflammation or neuroinflammation commonly noted in neurodegenerative disorders, also have a relevant influence on AHN $[49,54,59]$. Due to the interconnection between neuroinflammation and neurodegeneration in $\mathrm{AD}$, in this review, we summarize the current evidence regarding the impact of neuroinflammation on AHN and its relevance to $\mathrm{AD}$. In addition, we discuss the potential therapeutic strategies regarding this issue.

\section{Adult Neurogenesis and Its Alteration in AD}

\subsection{Neurogenesis in Adult Human Brains}

The concept of adult neurogenesis in humans was first published in 1998 by examining bromodeoxyuridine (BrdU)+ cells in the postmortem tissue from cancer patients [60]. In 2010, evidence of neurogenesis was reported using the technique of immunohistochemistry to identify the neurogenesis markers in postmortem human brain tissue samples [61]. The discovery of rostral migratory stream (RMS) reported by Sanai et al. [62] suggested the rudimentary continued olfactory neurogenesis. Although the presence of RMS is active in fetal age of human brain, it remains controversial in the adult brain [50]. Debates also existed due to contradictory findings of detectable hippocampal neurogenesis in adult human brains. A report noted that young neurons were detected in only the first year of life. Then, the recruitment of young neurons did not continue in the following years and was even extremely rare in the adult brain [63]. However, there is growing evidence supporting the presence of AHN in humans [47,64]. Moreno-Jimeńezetal et al. noted that the recruitment of new neurons can still occur and be detected in adulthood. With the shorter postmortem times and well-characterized fixation protocols, thousands of new neurons or immature neurons were detected in the dentate gyrus in neurologically healthy human subjects between middle age and the ninth decade of their life [47]. Improvements in study protocols and tissue preservation techniques have helped to detect the recruitment of new neurons in the human brain, therefore, supporting the presence of AHN in adulthood.

Although the evidence may not be sufficient to completely characterize the role of AHN, most researchers suggest that it can contribute to brain plasticity in adulthood. Potential functions of adult neurogenesis include increasing resilience against stress [65], improving pattern separation [66] and formation of memory and learning [67,68], and enhancing the loss of established or old memories [69]. Therefore, AHN plays a role in hippocampal plasticity $[66,70]$, and the continuous addition of these new neurons in the dentate gyrus remodels the hippocampal circuits.

Increasing evidence has shown that many behavioral factors regulate adult neurogenesis. Running and enriched environmental stimulation can induce neurogenesis [71-73]. In contrast, chronic stress can suppress the proliferation of NSCs $[74,75]$. The amount of neurogenesis also depends on the individual's age. During aging, NSCs and their progenitor cells reduced cellular proliferation and neuronal production [76-78]. A recent report found approximately 42,000 immature neurons $/ \mathrm{mm}^{2}$ in the brain of a 43-year-old donor, but the number of immature neurons dropped by approximately $30 \%$ in the brain of the elder donor at the age of near 90 years [79]. Age-related neurodegenerative diseases, such as AD, have different impacts on NSC maintenance, proliferation, survival, and functional integration. Impaired neurogenesis in neurodegenerative disorders can cause the sustained loss of 
live neurons with a diminished renewal capacity. This can have an impact on the pathophysiological mechanisms of these neurodegenerative diseases.

\subsection{Evidence Regarding Alteration in Adult Neurogenesis in $A D$}

Adult neurogenesis has been studied in different transgenic animal models of AD with largely different experimental conditions, depending on the use of PSEN1, PSEN2, or different APP single mutation or the combinations. In addition, the regimens, doses, and the time points for analysis after BrdU treatment were also varied in these studies. However, under different conditions, altered and dysfunctional neurogenesis was noted in both the SVZ and SGZ of the dentate gyrus [80]. Such compromised neurogenesis can precede the onset of hallmark lesions and neuronal loss [80]. Mostly, adult neurogenesis is impaired in the AD transgenic model with a single mutation of PSEN1 [81-83]. APP transgenic single mutation (PDAPP) with the use of the PDGF promotor also negatively impacted on the proliferation and survival of NPCs, especially in the aged state after amyloid deposition [84]. However, double or triple mutations of APP (APP751swe, APPswe, Ind.) led to increased proliferation and differentiation of new neurons [85-88]. The increase in neurogenesis could be explained by a compensatory response to pathological protein accumulation [85]. Another report used eight-month-old APP/PS1 mice to show decreases in quiescent nestin-positive astrocyte-like stem cells with preserved numbers in transient amplifying progenitor cells. However, both cells exhibited morphological abnormalities during amyloid deposition [89]. These findings provide evidence that the amyloidogenic environment leads to NPC dysfunction and that AHN is altered differently in various animal models of $\mathrm{AD}$. In addition to transgenic animal models of $\mathrm{AD}$, intracerebroventricular (ICV) injections of a low and subdiabetogenic doses of streptozotocin (STZ) have been demonstrated to be a new nontransgenic animal model to mimic human sporadic AD [90]. ICV injection of STZ induced oxidative stress, neuroinflammation, cerebral cholinergic deficits, and cognitive deficits that mimic AD. In this nontransgenic AD animal model, an ICV injection of STZ negatively impacted the generation of immature and mature neurons in the long-term period (three months) [91].

Variable findings in adult neurogenesis were also observed in human AD brains. One earlier report demonstrated that AD brains had higher expression of DCX, PSA-NCAM, TOAD-64/Ulip/CRMP (TUC-4), and NeuroD than that in the brains of normal subjects, indicating increased neurogenesis in the human AD brains [85]. Another report exhibited an increased number of Ki-67+ cells in the CA1-3 region of presenile human AD brains, reflecting an increase in glial- and vasculature-associated changes, but no altered neurogenesis was revealed in the dentate gyrus [92]. However, contradictory data existed. Dramatically decreased expression of the mature neuronal marker high molecular weight microtubule-associated protein (MAP) isoforms MAP2a was found in the dentate gyrus of human AD brains, indicating a failure of neuronal maturation in the hippocampus [93]. Another study reported a decrease in DCX+ and Sox $2+$ cells in the dentate gyrus of AD hippocampus as compared with nondemented control cases [94]. Recently, Moreno-Jimeńezetal et al. [79] used tightly controlled conditions and state-of-the-art tissue processing methods to study AHN in 45 patients with $\mathrm{AD}$ between 52 and 97 years of age. The number of DCX+ cells markedly declined as the AD neuropathological stage advanced. In addition, the number of DCX+ cell was consistently lower in AD patients than in neurologically healthy controls, regardless of age. They found that AHN was altered during the early stages of AD, even in the Braak stage I or II, in which the NFT was confined in the transentorhinal region of the brain. These data provide evidence that the neurogenesis in AD differs from physiological age-related altered neurogenesis. Some independent pathophysiological mechanisms could contribute to impaired $\mathrm{AHN}$ in $\mathrm{AD}$, even in the early stage of the disease.

\subsection{Known Modulators of Adult Neurogenesis and the Effects of AD on Adult Neurogenesis}

Multiple intrinsic and extrinsic factors have been reported to regulate adult neurogenesis. Known intrinsic modulators include signal transduction pathways (Wnt signaling, Notch signaling, Sonic hedgehog signaling (Shh), and Eph:ephrin signaling) [95-102]; epigenetic modulators, such 
as methyl-CpG-binding domains (MBD)-1 [103], methyl-CpG-binding protein 2 (MeCP2) [104], DNA-damage-inducible protein 45 beta (Gadd45b) [105], histone acetylation (HDAC3, HDAC5, and HDAC7) [106], and microRNAs (Let-7b, miR-9, miR-34a, and miR184) [106]; and genetic variation, such as RE-1 silencing transcription factor gene (REST) [107] and G-coupled protein receptor adenosine receptor A2A (ADORA2A) [108]. Extrinsic modulators include metabolic growth factors, such as VEFG, BDNF, IGF-1, FGF-2, IGF, and PDGF, which play a role in contributing to the proliferation, migration, cell fate determination, and maturation of NSCs or NPCs [109-113]. Another extrinsic modulator includes vasculature and angiogenesis, in which some reports suggested that the vascular beds of SVZ and SGZ support neurogenesis, and that endothelial cells promote the proliferation, differentiation, and survival of NSCs [114-116]. The immune system is another important modulator of adult neurogenesis. Various studies have demonstrated that inflammation affects adult neurogenesis by either proneurogenic effects or antineurogenic effects. Whether the effect enhances or inhibits depends on how to activate microglia, macrophages, or astrocytes and the duration of inflammation $[117,118]$. A previous study showed that resting microglia removed the apoptotic newborn neuroblasts by phagocytosis, indicating that microglia contribute to maintaining the homeostasis of the neurogenesis cascade in the dentate gyrus [119]. Another in vitro study also provided data that microglia have an instructive role for neuronal cell differentiation [120]. However, activated microglia, especially the classically activated proinflammatory (M1) phenotype, promote inflammation and play a role in suppressing hippocampal neurogenesis by reducing the survival of neuroblasts [121-123]. One landmark animal study, published in 2003, showed that peripheral injection of lipopolysaccharide (LPS) decreased the number of DCX+ cells and increased the number of microglia in the dentate gyrus. This LPS-induced attenuation of AHN was reversed by non-steroid anti-inflammatory drugs [122]. Moreover, long-term peripheral LPS injections for 28 days in adult mice had a long-term negative impact on AHN [121]. In addition to the effect of microglia and the duration of inflammation, some cytokines or chemokines, such as IL-1 $\alpha$, IL-6, IL-10, CX3CL1, CXCL1, and CXCL12 have important roles in positively regulating neurogenesis [124-130]. The proinflammatory cytokines released by activated microglia or astrocytes, such as IL- $1 \beta$, TNF- $\alpha$, IL-18, and IFN- $\gamma$, and some chemokines, such as CCL11, negatively impact the proliferation or differentiation of NSCs [131-134]. The duration of exposure of these cytokines or chemokines also has different effects on neurogenesis. For example, acute exposure of IL-6 cocultured with adult rat hippocampal NSCs for six to seven days significantly induced the differentiation of NSCs [124], but long-term exposure of the brain to IL-6 interfered with adult neurogenesis [135]. Briefly, neuroinflammation could be beneficial as a physiological response to maintain brain homeostasis but could also be detrimental to adult neurogenesis while it turns out to be a chronic process.

How AD affects adult neurogenesis is still a matter of debate, but a certain number of molecules central to AD have been noted to play a regulatory role in adult neurogenesis. PSEN1, a catalytic core of the aspartyl protease $\gamma$-secrease, regulates NPC differentiation in the adult brain through EGFR and Wnt/ $\beta$-catenin signaling [136]. Downregulation of PSEN1 in hippocampal NPCs caused the morphological changes of decreased dendritic branching and dendritic spines and deficits in pattern separation and novelty exploration in behavioral tests [137]. One of the APP metabolites, soluble APP (sAPP), a cleavage product following APP cleavage by $\alpha$-secretase, promoted neurite outgrowth in neurons differentiating from NPCs [138]. Other APP metabolites, such as sAPP- $\alpha$, sAPP- $\beta$, A $\beta$ peptides, and APP intracellular C-terminal domain (AICD) appear to modulate various functions in NSCs, including proliferation, neurogenesis, gliogenesis, or cell death [139]. Scopa, et al. [140] reported neurogenesis defects in a prodromal asymptomatic age (1.5 months of age) of TG2576 transgenic mice, in which the proliferation of NSCs was significantly reduced and the NSCs failed to differentiate into mature neurons. This reduction depended on the formation and accumulation of intracellular $A \beta$ oligomers in NSCs, indicating the negative impact of A $\beta$ oligomers on neurogenesis. AICD forms a transcriptionally active complex with Fe65 and Tip60 to regulate the expression of several genes, including PTCH1 (ptch1, receptor to suppress the Shh signaling in the absence of Shh ligands) [141] and 
Sox2 (transcription factor to regulate the embryonic development and cell fate determination) [142], and as previously discussed, plays a role in neurogenesis. Disintegrin-metalloproteinases (ADAMs) have $\alpha$-secretase activity in vivo and are known for alpha site proteolysis of APP. ADAM10-knockout mice had a prominent decrease in the number of NPCs in the SGZ and the activation of Notch-1 and its downstream target gene was impaired in ADAM-deficient hippocampal tissue [143]. ADAM 17 processes many substrates, including Notch and the EGFR ligand, and are critical for multipolar exit and radial migration of neuronal intermediate progenitor cells [144]. ADAM 21 was shown to be expressed in the adult SVZ cells and was associated with the migration and differentiation of neuroblasts [145]. Hyperphosphorylation of tau protein has an impact on neurogenesis. In young APPswe/PS1 $\triangle E 9$ mice, neurogenesis is impaired in the SVZ, and NPC proliferation and early differentiation are especially impaired [146]. In this area, the $A \beta$ was relatively low, but hyperphosphorylation of tau was significantly increased as early as two months of age $[80,146]$. Moreover, glycogen synthase kinase $3 \beta$ (GSK-3 $\beta$ ), which is the main kinase that phosphorylates tau in AD [147,148], also affects neurogenesis. GSK-3 $\beta$ overactivation increases the apoptosis of mature neurons, impairs the differentiation of neuroblasts, and reduces the number of proliferative clusters within the dentate gyrus $[149,150]$. The alteration of GSK-3 $\beta$ activity in the dentate gyrus could underlie the alterations in tau phosphorylation in these neurogenic niches of the brains [150].

\subsection{The Association between Altered Neurogenesis and AD Pathology}

One may question the causal relationship between altered neurogenesis and AD complex pathology. The above-mentioned evidence showed that many pathological metabolites (e.g., APP metabolites) or key regulators involved in the AD process (e.g., PSEN1 or GSK-3 $\beta$ ) play a role in influencing AHN. Is it possible that altered neurogenesis mediates AD pathologies? Choi et al. [151] recently used 5xFAD mice to study the relationship between neurogenesis and AD pathology. They use three models to block AHN by focal irradiation, DNA-ankylating agents (temozolomide, TMZ), and a lentivirus expressing a dominant-negative form of Wnt (LV-dnWnt). They found that a high degree of blocking AHN at a very early disease stage (six to eight weeks) did not affect the level of $A \beta$ deposition or the gliosis severity, but initiated mature neuron death and exacerbate cognitive dysfunction in later disease stages (five months) in 5xFAD mice. Such a phenomenon was not noted in wild-type mice. This suggests that early alteration of neurogenesis exerts no influence on $A \beta$ pathology, but impaired hippocampal neurogenesis in the early stage of $\mathrm{AD}$ could possibly increase hippocampal neuronal vulnerability, thus, leading to exacerbated cognitive impairment and increased neuronal loss in later stages of AD when the brain environment becomes more hostile.

\section{Neuroinflammation and Its Impact on Adult Neurogenesis in AD}

\subsection{Neuroinflammation in $A D$}

Neuroinflammation is the third core neuropathological feature in AD brains besides A $\beta$ or NFT. Activated astrocytes and microglia are found characteristically around neurons and plaques. Increased expression of several proinflammatory cytokines or inflammatory markers was also noted in AD brains $[152,153]$. This inflammatory reaction was proposed to be a response toward the progressive accumulation of $A \beta$ plaques and NFTs. Chronic or uncontrolled activation of these inflammatory processes is detrimental by inducing neuronal damage or death [154]. In the following section, we discuss many cellular components and mediators that constitute the neuroinflammation process in AD.

Microglia are the resident immune cells of the central nervous system. Similar to peripheral monocytes, they perform phagocytosis, antigen presenting, and produce immune mediators. In $A D$, microglia interact with $A \beta$ oligomers and fibrils with scavenger receptors (SCARA-1, MARCO, SCARB-1, CD36, and RAGE), G-protein coupled receptors (FPR2 and CMKLR1), toll-like receptors (TLR2, TLR4, TLR6, and TLR9), CD47, $\alpha 6 \beta 1$ integrin, and TERM2 [18,155,156]. After initial recognition, microglia are activated through the NF- $\mathrm{KB}$ pathway [157]. Due to the persistent encounter of $\mathrm{A} \beta$ and 
the inefficient phagocytosis clearance of fibrillar form A $\beta$ [158], microglia are persistently activated. Chronic activated microglia due to $A \beta$ produces proinflammatory mediators, which lead to decreased phagocytosis ability and prolong neuroinflammation [159]. Astrocytes are multifunctional glial cells involved in nutritional supplementation to neurons, waste clearance, and blood-brain barrier maintenance. In AD, astrocyte activation [160], astrogliosis, and astrocyte atrophy [161], indicated by increasing GFAP, could occur early in the disease course, even before amyloid plaque formation. $A \beta$ also activates astrocytes, possibly through the NF- $\mathrm{KB}$ pathway [162]. Activated astrocytes degrade $\mathrm{A} \beta$ itself and increase the phagocytosis of microglia through ApoE lipidation [163]. However, activated astrocytes also produce inflammatory mediators, contributing to the neuroinflammation process [164]. Oligodendrocytes are the source of myelin in the central nervous system. The role of oligodendrocytes in the neuroinflammation of AD is still largely unknown. In an in vitro study, oligodendrocytes are capable of complement synthesis, and thus could contribute to the neuroinflammation process [165].

Cytokines play a different role in neuroinflammation of AD. TNF- $\alpha$ increases A $\beta$ generation form APP through $\beta$ - and $\gamma$-secretase [166]. IL-1 increases the synthesis, secretion of APP, and generation of A $\beta$ [166]. IL-1 also increases the phosphorylation of tau protein through the p38-MAPK pathway [167]. IL-6 increases the expression of APP [168], and also increases the phosphorylation of tau protein through the $c d k 5 / p 35$ pathway [169]. Chemokines regulate microglial migration in the central nervous system. A $\beta$ increased the level of CXCR8, CCL2, CCL3, and CCL4 production in human mononuclear cells [170]. CX3CR1/CX3CL1 is important for maintaining the microglial resting state maintenance and synapse maturation and function [171]. In an animal model, CX3CR1/CX3CL1 was shown to be related to amyloid deposition and cognitive decline [172]. The complement system components in the central nervous system are produced by microglia, astrocytes, oligodendrocytes, and neurons [173]. In AD, the role of the complement system remains to be clarified. $C 1 q$ binds to $A \beta$ and activates the alternative complement pathway, leading to enhanced phagocytosis of $A \beta$ and neuroinflammation [174]. In an animal study, C3 deficiency was linked to impaired amyloid phagocytosis and increased $A \beta$ deposition [175]. A genome-wide association study revealed an association between apolipoprotein J, a complement inhibitor, and complement receptor 1, further indicating the potential contribution of complement system to AD [176].

\subsection{Evidence Regarding Neuroinflammation and Altered Neurogenesis in $A D$}

Since neuroinflammation is an important hallmark of $\mathrm{AD}$, it could have a remarkable influence on $\mathrm{AHN}$ in AD. The deposition of the A $\beta$ protein activates microglia and astrocytes, and this activation is accompanied by the secretion of inflammatory cytokines, such as IL-1 $\beta$, IL- 6 , and TNF- $\alpha$. These cytokines have been proven to have a negative impact on AHN, including a negative effect on NSC proliferation and survival, as discussed previously. Although there is still no direct evidence regarding the impact of neuroinflammation on AHN in human AD brains, some studies using AD animal models have demonstrated the association between neuroinflammation and neurogenesis. Bassani et al. reported that an ICV injection of STZ (an animal model of AD) increased immunoreactivity of the glial markers Iba- 1 and GFAP and decreased cell proliferation and the number of immature neurons (Ki-67+ and DCX+ cell) in the SVZ and dentate gyrus of the hippocampus [177]. Later, the same group used this rat model of $A D$ to demonstrate that STZ caused an acute and persistent neuroinflammatory response in the SVZ and dorsal hippocampus, impaired short-term and long-term spatial memory, and reduced the survival, differentiation, and maturation of newborn neurons, which supports the hypothesis that neuroinflammation negatively affects neurogenesis [178]. In addition, Mishara et al. [179] reported that an ICV injection of STZ significantly reduced the number of BrdU+ cells, BrdU+/Nestin + cells, and DCX+ cells in the SVZ and dentate gyrus, 11 and 18 days after the injection, indicating a negative influence on the proliferation of NSCs and migration of newborn neurons. A concurrent significant increase in the markers of neuroinflammation, including GFAP and NF- $\mathrm{B}$, was noted in the SVZ and hippocampus. This increase suggests an association between decreased neurogenesis and enhanced neuroinflammation in this kind of $\mathrm{AD}$ animal model. In the transgenic AD animal model, Kiyota 
et al. [127] used the adeno-associated virus (AAV) mediated gene delivery method to enhance the expression of the anti-inflammatory cytokine IL-10 in the hippocampus of APP/PS1 transgenic mice. The expression of IL-10 suppressed reactive gliosis and microglial accumulation around the plaque and enhanced neurogenesis by significantly increasing the number of BrdU+/NeuN + cells and DCX+ cells in the SGZ of the hippocampus. Further in vitro microglia/NSCs coculture systems demonstrated that IL-10 enhanced the proliferation of NSCs by stimulating microglia, but not by IL-10 alone. This result supports the role of microglia in regulating the function of neurogenesis. In another animal model of AD, Ghosal et al. [180] reported that AICD transgenic mice (coexpressing the 59-residue long AICD fragment and Fe65, which form the transcriptionally active complex to regulate several genes involved in in the process of neurogenesis) had reduced numbers of BrdU+ cells and DCX+ cells in the SGZ at three months of age to at least 12 months of age, thus, demonstrating decreased hippocampal neurogenesis. They also found a dramatic recruitment of CD45+ microglia and increased expression of proinflammatory cytokines in 12-week-old AICD transgenic mice. An increase of BrdU+ and DCX+ cells in the SGZ was noted after oral treatment with the non-steroidal anti-inflammatory drugs (NSAIDs), ibuprofen and naproxen, for nine weeks, beginning at three weeks of age, thus, indicating the association between reducing neuroinflammation and enhancing neurogenesis in AD transgenic mice. Valero et al. [181] studied the effect of single systemic inflammation induced by an intraperitoneally LPS injection on adult neurogenesis in a wild-type and triple-transgenic mouse model of AD (3xTg-AD). A single, systemic LPS injection in 3xTg-AD mice at four month of age aggravated long-term hippocampal-dependent spatial memory impairments seven weeks after the LPS injection. The number of DCX+ cells in 3xTg-AD mice significantly decreased as compared with that in wild-type mice, and LPS injection also decreased the number of synaptic puncta in the dendrites of DCX+ cells of 3xTG-AD mice, indicating that a single systemic inflammatory event also produces a long-term impairment on the formation of synaptic specializations in new born neurons of AD transgenic animal models.

Although there is a lack of direct evidence regarding neuroinflammation and neurogenesis in human AD brains, the above-mentioned findings support the association between neuroinflammation and altered neurogenesis in AD models. Further studies may be warranted to verify the exact causal relationship between these two phenomena, especially in the degenerative process of $\mathrm{AD}$. The findings of the above-mentioned changes between neuroinflammation and neurogenesis in AD animal models are summarized in Table 1. 
Table 1. The evidence regarding altered neurogenesis and inflammation or anti-inflammation in AD rodent models.

\begin{tabular}{|c|c|c|c|c|c|}
\hline Reference & Model & Observation Period & Neurogenesis (Location) & Inflammation/Anti-Inflammation & Behavior \\
\hline Bassani et al. (2017) [177] & ICV-STZ (Wistar rats) & 4 weeks & $\begin{array}{l}V_{\mathrm{Di}-67+}^{\mathrm{KCX}} \\
(\mathrm{SVZ}, \mathrm{DG})\end{array}$ & $\begin{array}{c}\text { 1 } \\
\text { A }_{\mathrm{GFAP}}^{\mathrm{Iba}-1} \\
(\mathrm{SVZ}, \mathrm{DG})\end{array}$ & $\begin{array}{l}\text { Impairment in short-term spatial memory } \\
\text { (object location test and } \mathrm{Y} \text { maze) and } \\
\text { short-term recognition memory (object } \\
\text { location test) }\end{array}$ \\
\hline Bassani et al. (2018) [178] & ICV-STZ (Wistar rats) & $\begin{array}{l}\text { Acute, } 7 \text { days } \\
\text { Late, } 30 \text { days }\end{array}$ & $\begin{array}{l}\text { Ki-67+ cell (DG and SVZ) in acute } \\
\text { period } \\
\text { BrdU+NeuN+ cell (DG) in late period } \\
\text { DCX+cell (DG and SVZ) in late period }\end{array}$ & $\begin{array}{l}\text { GFAP } \\
\text { (CA1 and } \mathrm{CA} 3, \mathrm{DG}) \text { in acute and late } \\
\text { period }\end{array}$ & $\begin{array}{l}\text { Impairment in short-term spatial memory } \\
\text { and long-term spatial memory (object } \\
\text { location test and Y maze) }\end{array}$ \\
\hline Mishra et al. (2018) [179] & ICV-STZ (Sprague Dawley rats) & Day 11 and Day 18 & $\begin{array}{l}\text { BrdU+Nestin+ cell } \\
\text { BrdU+NeuN + cell } \\
\text { DCX + cell } \\
\text { in Day } 11 \text { and Day } 18 \text { (DG and SVZ) }\end{array}$ & $\begin{array}{l}\text { GFAP } \\
\text { in Day } 18 \text { (DG and SVZ) }\end{array}$ & $\begin{array}{l}\text { Impairment in learning and memory } \\
\text { (Morris water maze test) (Day 18) }\end{array}$ \\
\hline Kiyota et al. (2012) [127] & $\begin{array}{l}\mathrm{APP}+\mathrm{PS} 1 \mathrm{Tg} \text { mice }+\mathrm{AAV} \text {-mediated } \\
\text { expression of IL-10 }\end{array}$ & 3 weeks & $\begin{array}{l}\text { DCX + cell } \\
\text { (SGZ of DG) }\end{array}$ & $\begin{array}{l}\text { IL-10 expression for anti-inflammation } \\
\text { reduced gliosis and microglial } \\
\text { accumulation around the plaque }\end{array}$ & N/A \\
\hline Ghosal et al. (2010) [180] & AICD Tg mice & 6 weeks & BrdU+DCX+cell (SGZ of DG) & $\begin{array}{l}\text { Anti-inflammation by oral NSAIDs } \\
\text { (lbuprofen and Naproxen) }\end{array}$ & N/A \\
\hline Volero et al. (2014) [181] & $3 \times \mathrm{TG}-\mathrm{AD}$ & 7 weeks & $\begin{array}{l}\text { DCX+ cell and synaptic puncta in the } \\
\text { dendrites of DCX + cell }\end{array}$ & Systemic inflammation by LPS injection & $\begin{array}{l}\text { Impairment in spatial memory (Morris } \\
\text { water maze test) }\end{array}$ \\
\hline
\end{tabular}

Downward arrow: reduced level; Upward arrow: increased level; N/A: not applicable. ICV, intraventricular; STZ, streptozotocin; DCX, doublecortin; BrdU, bromodeoxyuridine; GFAP, glial fibrillary acidic protein; Iba-1, ionized calcium binding adaptor molecule 1; SVZ, subventricular zone; DG, dentate gyrus; Tg, transgenic; NSAIDs, nonsteroidal anti-inflammatory drugs. 


\section{Potential Therapeutic Approaches Targeting Adult Neurogenesis and Inflammation}

It is unknown whether restoration of normal levels of adult neurogenesis becomes a potential therapeutic approach for slowing or reversing the progression of AD. Choi et al. [151] increased neurogenesis using a genetic method (mice received lentivirus expressing the WNT3 protein, LV-Wnt3, to increase the proliferation of NPCs) and a pharmacologic method (P7C3, a compound to enhance the survival of NPCs) in 5xFAD mice. They found that inducing neurogenesis alone had limited effects on improving cognition in AD transgenic mice. However, the method combined with pharmacologically increasing the level of BDNF (AMP-activated protein kinase agonist 5-aminoimidazole-4-carboxamide riboside) and neurogenesis activation by LV-Wnt 3 or P7C 3 ameliorated cognitive dysfunction in this AD model.

Dietary behavior, including caloric intake, meal frequency, meal texture, and meal content, has been reported to influence AHN [182]. The animal models showed that caloric restriction [183], hard-textured diet [184], and nutritional contents, such as polyunsaturated fatty acids (PUFA, such as omega-3 fatty acids) [185], polyphenols [186] (blueberries [187] and curcumin [188]), and vitamin D [189] positively regulate AHN and potentially restore behavioral impairment. Caloric restriction has neuroprotective roles in AD by increasing expression of neurogenesis-related genes and decreasing expression of inflammation-related genes in the PS1 and PS2 double knock-out mice [190]. Caloric restriction also enhances the expression of SIRT1, which is expressed in the hippocampus and is important for normal learning and memory. SIRT1 is involved in enhancing cell survival and neuronal differentiation [191,192]. In addition to enhancing neurogenesis, some nutritional contents also exert anti-inflammatory effects. PUFA exerted anti-inflammatory effects by affecting gene regulation involving inflammatory process in blood mononuclear leukocytes in AD patients [193]. Curcumin [194], quercetin [195], and caffeine/coffee [196,197] were shown to have anti-inflammatory roles, and therefore potentially beneficial for both AHN and protection against AD [198]. In addition to dietary intervention, probiotics, which are beneficial bacteria that modulate gut microbiota composition and function, have been shown to reduce neuroinflammation and restore cognitive deficits in AD animal model [199]. The supplementation of probiotics also increase BDNF mRNA in the hippocampus [200], thus potentially positively regulating AHN. However, the effect of probiotics supplementation on anti-inflammation or cognitive function in AD patients has not been very promising to date [201,202]. Future studies should focus on fields including proneurogenic and anti-inflammatory effects of dietary intervention and the modulation of gut microbiota and their therapeutic impact in AD models [198,203].

Another positive regulator of adult neurogenesis, environmental enrichment, has been demonstrated not only to reduce $\mathrm{A} \beta$ levels and amyloid deposition but also to reverse the impairment of adult neurogenesis and cognitive dysfunction in APPswe/PS1DE9 mice and APP23 mice [88,204]. However, negative results have been reported regarding the effect of environmental enrichment on adult neurogenesis in transgenic mice harboring FAD-linked PS1 mutations [83].

During the past decades, exercise has been demonstrated to exert repeated and robust beneficial effects on hippocampal neurogenesis. Praag et al. reported that voluntary running increased the proliferation and survival of new neurons in the dentate gyrus and long-term wheel running increased both hippocampal neurogenesis and the spatial learning abilities $[205,206]$. Such proneurogenic effects of running and improving performance of memory tasks have been demonstrated in different experimental paradigms in wild-type rodent models $[207,208]$ and also in AD rodent models $[151,209,210]$. In human studies, there is a lack of direct evidence to reveal the relationship between exercise and enhancing neurogenesis. However, exercise has been shown to improve the memory tasks by different exercise training protocols in healthy populations [211] or diseased populations, such as patients with Parkinson's disease [212] or $\mathrm{AD}$ [213].

Recently, some reports have suggested that voluntary exercise could have anti-inflammatory effects in the brain [214,215]. Animal studies have also proven that exercise restores the level of impaired neurogenesis induced by neuroinflammation [216]. However, there is as yet no direct evidence regarding the impact of exercise on neuroinflammation and neurogenesis in AD animal 
models. Parachikova et al. [217] reported that voluntary exercise in Tg2576 aged mice not only improved their spatial learning ability but also increased hippocampal expression of CXCL1 and CXCL12, which have been reported to have proneurogenic effects $[129,130]$. Nichol et al. $[218,219]$ also reported that exercise reduced the expression of TNF- $\alpha$ and IL-1 $\beta$ in the hippocampus of aged Tg2576 mice. The use of an in-cage running wheel for three weeks also reduced the level of soluble $A \beta$ and soluble fibrillary $A \beta$ in transgenic mice. However, contradictory results have shown that exercise has no effect on modulating neuroinflammation [219]. Although some variant data have been reported, exercise could have a potential for AD-associated neuroinflammation and impaired neurogenesis. Future directions should focus on the proneurogenic and anti-inflammatory effects of exercise and its therapeutic impact in AD models.

Because neuroinflammation and their related cytokines or chemokines exert negative impacts on adult neurogenesis, some therapeutic approaches targeting inflammatory cells or inflammatory molecules to manipulate neurogenesis have been reported. In Ghosal's report, impaired neurogenesis in AICD transgenic mice was prevented by oral treatment with buprofen and naproxen [180]. However, other studies focused on NSAIDs [220], or glucocorticoid steroids [221], in AD have not been very promising to date. Future studies are required to draw solid conclusions about the anti-inflammatory drugs on altered neurogenesis as a disease-modifying therapy for AD.

Figure 1 summarizes the potential therapeutic approaches listed in above section.

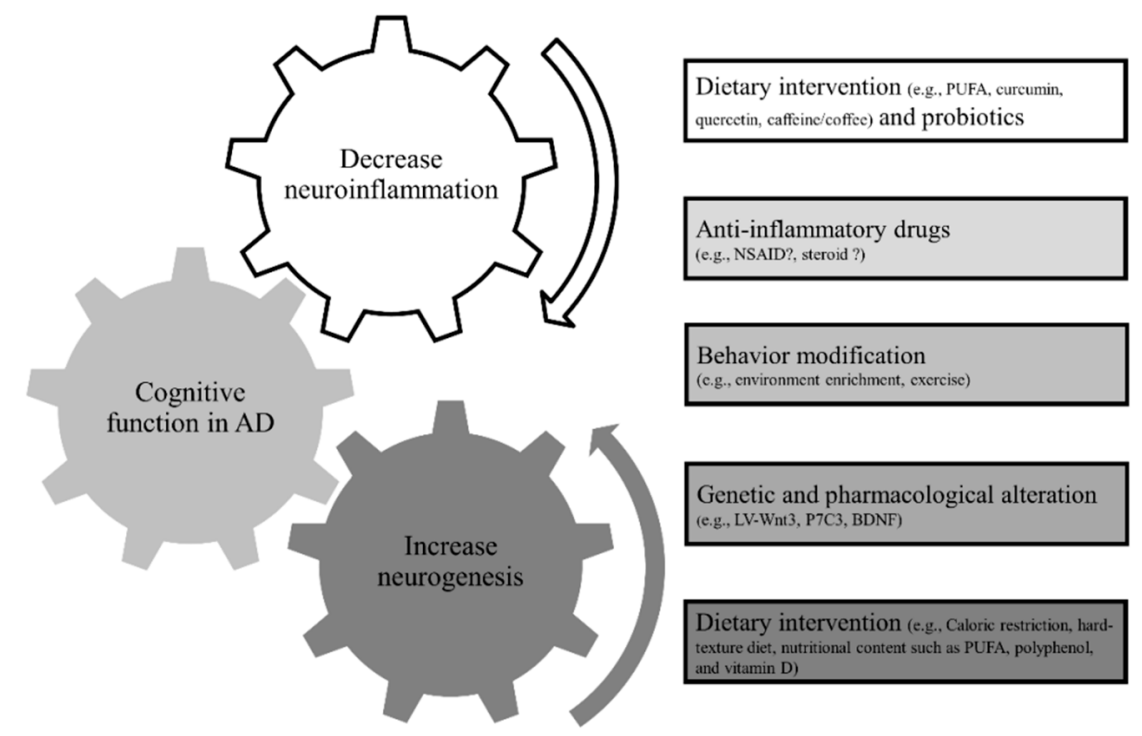

Figure 1. The potential therapeutic approaches targeting adult neurogenesis and inflammation in AD. PUFA, poly-unsaturated fatty acids; NSAID, nonsteroidal anti-inflammatory drugs; and LV-Wnt3, lentivirus expressing the WNT3 protein.

\section{Conclusions}

Neurogenesis exists in aged human brain and its level is indeed decreased in human AD brain as compared with that in healthy controls. Animal models correspondingly supported that early impairment of neurogenesis could increase neuronal vulnerability in the hostile brain environment of AD. Inflammation is one of the central etiologies influencing the process of altered neurogenesis in AD. A better understanding regarding the interactions between altered neurogenesis and neuroinflammation in $\mathrm{AD}$ is required to develop a potential novel approach focused on modulating these two phenomena to ameliorate the neurodegenerative process of this disease. 
Author Contributions: P.-S.S. and P.-Y.L. literature review, table and original manuscript preparation; C.-H.L. and H.-C.S. manuscript review and editing; P.-S.S. and K.-J.T. fund acquisition, conception and design, manuscript review and editing, and final approval of the manuscript. All authors have read and agreed to the published version of the manuscript.

Funding: This study was supported by grants from the Ministry of Science and Technology, Taiwan (MOST-105-2628-B-006-016-MY3 and MOST-106-2628-B-006-001-MY4) and a grant from the National Cheng Kung University Hospital (NCKUH-2020350).

Conflicts of Interest: The authors declare no conflict of interest.

\section{References}

1. Jack, C.R., Jr.; Bennett, D.A.; Blennow, K.; Carrillo, M.C.; Dunn, B.; Haeberlein, S.B.; Holtzman, D.M.; Jagust, W.; Jessen, F.; Karlawish, J.; et al. NIA-AA Research Framework: Toward a biological definition of Alzheimer's disease. Alzheimers Dement. 2018, 14, 535-562. [CrossRef] [PubMed]

2. Scheltens, P.; Blennow, K.; Breteler, M.M.; de Strooper, B.; Frisoni, G.B.; Salloway, S.; Van der Flier, W.M. Alzheimer's disease. Lancet 2016, 388, 505-517. [CrossRef] [PubMed]

3. Mattson, M.P. Pathways towards and away from Alzheimer's disease. Nature 2004, 430, 631-639. [CrossRef] [PubMed]

4. De-Paula, V.J.; Radanovic, M.; Diniz, B.S.; Forlenza, O.V. Alzheimer's disease. SubCell. Biochem. 2012, 65, 329-352. [CrossRef]

5. Jansen, W.J.; Ossenkoppele, R.; Knol, D.L.; Tijms, B.M.; Scheltens, P.; Verhey, F.R.; Visser, P.J.; Aalten, P.; Aarsland, D.; Alcolea, D.; et al. Prevalence of cerebral amyloid pathology in persons without dementia: A meta-analysis. JAMA 2015, 313, 1924-1938. [CrossRef]

6. Santa-Maria, I.; Varghese, M.; Ksiezak-Reding, H.; Dzhun, A.; Wang, J.; Pasinetti, G.M. Paired helical filaments from Alzheimer disease brain induce intracellular accumulation of Tau protein in aggresomes. J. Biol. Chem. 2012, 287, 20522-20533. [CrossRef]

7. Yeboah, F.; Kim, T.E.; Bill, A.; Dettmer, U. Dynamic behaviors of alpha-synuclein and tau in the cellular context: New mechanistic insights and therapeutic opportunities in neurodegeneration. Neurobiol. Dis. 2019, 132, 104543. [CrossRef]

8. Varghese, M.; Santa-Maria, I.; Ho, L.; Ward, L.; Yemul, S.; Dubner, L.; Ksiezak-Reding, H.; Pasinetti, G.M. Extracellular Tau Paired Helical Filaments Differentially Affect Tau Pathogenic Mechanisms in Mitotic and Post-Mitotic Cells: Implications for Mechanisms of Tau Propagation in the Brain. J. Alzheimers Dis. 2016, 54, 477-496. [CrossRef]

9. Goedert, M. NEURODEGENERATION. Alzheimer's and Parkinson's diseases: The prion concept in relation to assembled Abeta, tau, and alpha-synuclein. Science 2015, 349, 1255555. [CrossRef]

10. Okamura, N.; Harada, R.; Furumoto, S.; Arai, H.; Yanai, K.; Kudo, Y. Tau PET imaging in Alzheimer's disease. Curr. Neurol. Neurosci. Rep. 2014, 14, 500. [CrossRef]

11. Wang, Y.T.; Edison, P. Tau Imaging in Neurodegenerative Diseases Using Positron Emission Tomography. Curr. Neurol. Neurosci. Rep. 2019, 19, 45. [CrossRef] [PubMed]

12. Wang, J.; Tan, L.; Yu, J.T. Prevention Trials in Alzheimer's Disease: Current Status and Future Perspectives. J. Alzheimers Dis. 2016, 50, 927-945. [CrossRef] [PubMed]

13. Schilling, S.; Rahfeld, J.U.; Lues, I.; Lemere, C.A. Passive Abeta Immunotherapy: Current Achievements and Future Perspectives. Molecules 2018, 23, 1068. [CrossRef]

14. Hoskin, J.L.; Sabbagh, M.N.; Al-Hasan, Y.; Decourt, B. Tau immunotherapies for Alzheimer's disease. Expert Opin. Investig. Drugs 2019, 28, 545-554. [CrossRef] [PubMed]

15. Panza, F.; Lozupone, M.; Seripa, D.; Imbimbo, B.P. Amyloid-beta immunotherapy for alzheimer disease: Is it now a long shot? Ann. Neurol. 2019, 85, 303-315. [CrossRef]

16. Kokjohn, T.A.; Maarouf, C.L.; Roher, A.E. Is Alzheimer's disease amyloidosis the result of a repair mechanism gone astray? Alzheimers Dement. 2012, 8, 574-583. [CrossRef]

17. Krstic, D.; Knuesel, I. Deciphering the mechanism underlying late-onset Alzheimer disease. Nat. Rev. Neurol. 2013, 9, 25-34. [CrossRef]

18. Aminzadeh, M.; Roghani, M.; Sarfallah, A.; Riazi, G.H. TRPM2 dependence of ROS-induced NLRP3 activation in Alzheimer's disease. Int. Immunopharmacol. 2018, 54, 78-85. [CrossRef] 
19. Kinney, J.W.; Bemiller, S.M.; Murtishaw, A.S.; Leisgang, A.M.; Salazar, A.M.; Lamb, B.T. Inflammation as a central mechanism in Alzheimer's disease. Alzheimer's Dement. Transl. Res. Clin. Interv. 2018, 4, 575-590. [CrossRef]

20. Castellani, R.J.; Lee, H.G.; Zhu, X.; Perry, G.; Smith, M.A. Alzheimer disease pathology as a host response. J. Neuropathol. Exp. Neurol. 2008, 67, 523-531. [CrossRef]

21. Struble, R.G.; Ala, T.; Patrylo, P.R.; Brewer, G.J.; Yan, X.X. Is brain amyloid production a cause or a result of dementia of the Alzheimer's type? J. Alzheimers Dis. 2010, 22, 393-399. [CrossRef] [PubMed]

22. Castello, M.A.; Soriano, S. Rational heterodoxy: Cholesterol reformation of the amyloid doctrine. Ageing Res. Rev. 2013, 12, 282-288. [CrossRef] [PubMed]

23. Lumsden, A.L.; Rogers, J.T.; Majd, S.; Newman, M.; Sutherland, G.T.; Verdile, G.; Lardelli, M. Dysregulation of Neuronal Iron Homeostasis as an Alternative Unifying Effect of Mutations Causing Familial Alzheimer's Disease. Front. Neurosci. 2018, 12, 533. [CrossRef] [PubMed]

24. Hoozemans, J.J.; Veerhuis, R.; Rozemuller, J.M.; Eikelenboom, P. Neuroinflammation and regeneration in the early stages of Alzheimer's disease pathology. Int. J. Dev. Neurosci. Off. J. Int. Soc. Dev. Neurosci. 2006, 24, 157-165. [CrossRef]

25. Cai, Z.; Hussain, M.D.; Yan, L.J. Microglia, neuroinflammation, and beta-amyloid protein in Alzheimer's disease. Int. J. Neurosci. 2014, 124, 307-321. [CrossRef]

26. Doens, D.; Fernandez, P.L. Microglia receptors and their implications in the response to amyloid beta for Alzheimer's disease pathogenesis. J. Neuroinflamm. 2014, 11, 48. [CrossRef]

27. Heneka, M.T.; Carson, M.J.; El Khoury, J.; Landreth, G.E.; Brosseron, F.; Feinstein, D.L.; Jacobs, A.H.; Wyss-Coray, T.; Vitorica, J.; Ransohoff, R.M.; et al. Neuroinflammation in Alzheimer's disease. Lancet Neurol. 2015, 14, 388-405. [CrossRef]

28. Calsolaro, V.; Edison, P. Neuroinflammation in Alzheimer's disease: Current evidence and future directions. Alzheimers Dement. 2016, 12, 719-732. [CrossRef]

29. Piirainen, S.; Youssef, A.; Song, C.; Kalueff, A.V.; Landreth, G.E.; Malm, T.; Tian, L. Psychosocial stress on neuroinflammation and cognitive dysfunctions in Alzheimer's disease: The emerging role for microglia? Neurosci. Biobehav. Rev. 2017, 77, 148-164. [CrossRef]

30. Loffler, T.; Flunkert, S.; Havas, D.; Schweinzer, C.; Uger, M.; Windisch, M.; Steyrer, E.; Hutter-Paier, B. Neuroinflammation and related neuropathologies in APPSL mice: Further value of this in vivo model of Alzheimer's disease. J. Neuroinflamm. 2014, 11, 84. [CrossRef]

31. Nazem, A.; Sankowski, R.; Bacher, M.; Al-Abed, Y. Rodent models of neuroinflammation for Alzheimer's disease. J. Neuroinflamm. 2015, 12, 74. [CrossRef]

32. Gomez-Nicola, D.; Boche, D. Post-mortem analysis of neuroinflammatory changes in human Alzheimer's disease. Alzheimers Res. Ther. 2015, 7, 42. [CrossRef] [PubMed]

33. Wilcock, D.M.; Hurban, J.; Helman, A.M.; Sudduth, T.L.; McCarty, K.L.; Beckett, T.L.; Ferrell, J.C.; Murphy, M.P.; Abner, E.L.; Schmitt, F.A.; et al. Down syndrome individuals with Alzheimer's disease have a distinct neuroinflammatory phenotype compared to sporadic Alzheimer's disease. Neurobiol. Aging 2015, 36, 2468-2474. [CrossRef] [PubMed]

34. Sudduth, T.L.; Schmitt, F.A.; Nelson, P.T.; Wilcock, D.M. Neuroinflammatory phenotype in early Alzheimer's disease. Neurobiol. Aging 2013, 34, 1051-1059. [CrossRef] [PubMed]

35. Zimmer, E.R.; Leuzy, A.; Benedet, A.L.; Breitner, J.; Gauthier, S.; Rosa-Neto, P. Tracking neuroinflammation in Alzheimer's disease: The role of positron emission tomography imaging. J. Neuroinflamm. 2014, 11, 120. [CrossRef] [PubMed]

36. Chandra, A.; Valkimadi, P.E.; Pagano, G.; Cousins, O.; Dervenoulas, G.; Politis, M. Applications of amyloid, tau, and neuroinflammation PET imaging to Alzheimer's disease and mild cognitive impairment. Hum. Brain Mapp. 2019. [CrossRef]

37. Tan, L.; Yu, J.T.; Zhang, W.; Wu, Z.C.; Zhang, Q.; Liu, Q.Y.; Wang, W.; Wang, H.F.; Ma, X.Y.; Cui, W.Z. Association of GWAS-linked loci with late-onset Alzheimer's disease in a northern Han Chinese population. Alzheimers Dement. 2013, 9, 546-553. [CrossRef]

38. Chouraki, V.; Seshadri, S. Genetics of Alzheimer's disease. Adv. Genet. 2014, 87, 245-294. [CrossRef]

39. Villegas-Llerena, C.; Phillips, A.; Garcia-Reitboeck, P.; Hardy, J.; Pocock, J.M. Microglial genes regulating neuroinflammation in the progression of Alzheimer's disease. Curr. Opin. Neurobiol. 2016, 36, 74-81. [CrossRef] 
40. Katsumata, Y.; Nelson, P.T.; Estus, S.; Fardo, D.W. Translating Alzheimer's disease-associated polymorphisms into functional candidates: A survey of IGAP genes and SNPs. Neurobiol. Aging 2019, 74, 135-146. [CrossRef]

41. Takatori, S.; Wang, W.; Iguchi, A.; Tomita, T. Genetic Risk Factors for Alzheimer Disease: Emerging Roles of Microglia in Disease Pathomechanisms. Adv. Exp. Med. Biol. 2019, 1118, 83-116. [CrossRef] [PubMed]

42. Bamberger, M.E.; Landreth, G.E. Microglial interaction with beta-amyloid: Implications for the pathogenesis of Alzheimer's disease. Microsc. Res. Tech. 2001, 54, 59-70. [CrossRef] [PubMed]

43. Kitazawa, M.; Yamasaki, T.R.; LaFerla, F.M. Microglia as a potential bridge between the amyloid beta-peptide and tau. Ann. N. Y. Acad. Sci. 2004, 1035, 85-103. [CrossRef] [PubMed]

44. Garwood, C.J.; Pooler, A.M.; Atherton, J.; Hanger, D.P.; Noble, W. Astrocytes are important mediators of Abeta-induced neurotoxicity and tau phosphorylation in primary culture. Cell Death Dis. 2011, 2, e167. [CrossRef]

45. Veerhuis, R.; Van Breemen, M.J.; Hoozemans, J.M.; Morbin, M.; Ouladhadj, J.; Tagliavini, F.; Eikelenboom, P. Amyloid beta plaque-associated proteins $\mathrm{C} 1 \mathrm{q}$ and SAP enhance the Abeta1-42 peptide-induced cytokine secretion by adult human microglia in vitro. Acta Neuropathol. 2003, 105, 135-144. [CrossRef]

46. Gage, F.H. Adult neurogenesis in mammals. Science 2019, 364, 827-828. [CrossRef]

47. Moreno-Jimenez, E.P.; Flor-Garcia, M.; Terreros-Roncal, J.; Rabano, A.; Cafini, F.; Pallas-Bazarra, N.; Avila, J.; Llorens-Martin, M. Adult hippocampal neurogenesis is abundant in neurologically healthy subjects and drops sharply in patients with Alzheimer's disease. Nat. Med. 2019, 25, 554-560. [CrossRef]

48. Doetsch, F.; Hen, R. Young and excitable: The function of new neurons in the adult mammalian brain. Curr. Opin. Neurobiol. 2005, 15, 121-128. [CrossRef]

49. Horgusluoglu, E.; Nudelman, K.; Nho, K.; Saykin, A.J. Adult neurogenesis and neurodegenerative diseases: A systems biology perspective. Am. J. Med Genet. Part B Neuropsychiatr. Genet. 2017, 174, 93-112. [CrossRef]

50. Kumar, A.; Pareek, V.; Faiq, M.A.; Ghosh, S.K.; Kumari, C. ADULT NEUROGENESIS IN HUMANS: A Review of Basic Concepts, History, Current Research, and Clinical Implications. Innov. Clin. Neurosci. 2019, 16, 30-37.

51. Elder, G.A.; De Gasperi, R.; Gama Sosa, M.A. Research update: Neurogenesis in adult brain and neuropsychiatric disorders. Mt. Sinai J. Med. N. Y. 2006, 73, 931-940.

52. Bielefeld, P.; Dura, I.; Danielewicz, J.; Lucassen, P.J.; Baekelandt, V.; Abrous, D.N.; Encinas, J.M.; Fitzsimons, C.P. Insult-induced aberrant hippocampal neurogenesis: Functional consequences and possible therapeutic strategies. Behav. Brain Res. 2019, 372, 112032. [CrossRef] [PubMed]

53. Hayashi, Y.; Jinnou, H.; Sawamoto, K.; Hitoshi, S. Adult neurogenesis and its role in brain injury and psychiatric diseases. J. Neurochem. 2018, 147, 584-594. [CrossRef] [PubMed]

54. Winner, B.; Kohl, Z.; Gage, F.H. Neurodegenerative disease and adult neurogenesis. Eur. J. Neurosci. 2011, 33, 1139-1151. [CrossRef]

55. Grote, H.E.; Hannan, A.J. Regulators of adult neurogenesis in the healthy and diseased brain. Clin. Exp. Pharmacol. Physiol. 2007, 34, 533-545. [CrossRef]

56. Curtis, M.A.; Kam, M.; Faull, R.L. Neurogenesis in humans. Eur. J. Neurosci. 2011, 33, 1170-1174. [CrossRef]

57. Gil-Mohapel, J.; Simpson, J.M.; Ghilan, M.; Christie, B.R. Neurogenesis in Huntington's disease: Can studying adult neurogenesis lead to the development of new therapeutic strategies? Brain Res. 2011, 1406, 84-105. [CrossRef]

58. Marxreiter, F.; Regensburger, M.; Winkler, J. Adult neurogenesis in Parkinson's disease. Cell. Mol. Life Sci. 2013, 70, 459-473. [CrossRef]

59. Chesnokova, V.; Pechnick, R.N.; Wawrowsky, K. Chronic peripheral inflammation, hippocampal neurogenesis, and behavior. Brain Behav. Immun. 2016, 58, 1-8. [CrossRef]

60. Eriksson, P.S.; Perfilieva, E.; Björk-Eriksson, T.; Alborn, A.-M.; Nordborg, C.; Peterson, D.A.; Gage, F.H. Neurogenesis in the adult human hippocampus. Nat. Med. 1998, 4, 1313. [CrossRef]

61. Knoth, R.; Singec, I.; Ditter, M.; Pantazis, G.; Capetian, P.; Meyer, R.P.; Horvat, V.; Volk, B.; Kempermann, G. Murine features of neurogenesis in the human hippocampus across the lifespan from 0 to 100 years. PLoS ONE 2010, 5, e8809. [CrossRef] [PubMed]

62. Sanai, N.; Nguyen, T.; Ihrie, R.A.; Mirzadeh, Z.; Tsai, H.-H.; Wong, M.; Gupta, N.; Berger, M.S.; Huang, E.; Garcia-Verdugo, J.-M. Corridors of migrating neurons in the human brain and their decline during infancy. Nature 2011, 478, 382. [CrossRef] [PubMed] 
63. Sorrells, S.F.; Paredes, M.F.; Cebrian-Silla, A.; Sandoval, K.; Qi, D.; Kelley, K.W.; James, D.; Mayer, S.; Chang, J.; Auguste, K.I.; et al. Human hippocampal neurogenesis drops sharply in children to undetectable levels in adults. Nature 2018, 555, 377-381. [CrossRef] [PubMed]

64. Boldrini, M.; Fulmore, C.A.; Tartt, A.N.; Simeon, L.R.; Pavlova, I.; Poposka, V.; Rosoklija, G.B.; Stankov, A.; Arango, V.; Dwork, A.J.; et al. Human Hippocampal Neurogenesis Persists throughout Aging. Cell Stem Cell 2018, 22, 589-599.e585. [CrossRef]

65. Levone, B.R.; Cryan, J.F.; O'Leary, O.F. Role of adult hippocampal neurogenesis in stress resilience. Neurobiol. Stress 2015, 1, 147-155. [CrossRef]

66. Sahay, A.; Scobie, K.N.; Hill, A.S.; O'Carroll, C.M.; Kheirbek, M.A.; Burghardt, N.S.; Fenton, A.A.; Dranovsky, A.; Hen, R. Increasing adult hippocampal neurogenesis is sufficient to improve pattern separation. Nature 2011, 472, 466-470. [CrossRef]

67. Bruel-Jungerman, E.; Rampon, C.; Laroche, S. Adult hippocampal neurogenesis, synaptic plasticity and memory: Facts and hypotheses. Rev. Neurosci. 2007, 18, 93-114.

68. Goodman, T.; Trouche, S.; Massou, I.; Verret, L.; Zerwas, M.; Roullet, P.; Rampon, C. Young hippocampal neurons are critical for recent and remote spatial memory in adult mice. Neuroscience 2010, 171, 769-778. [CrossRef]

69. Akers, K.G.; Martinez-Canabal, A.; Restivo, L.; Yiu, A.P.; De Cristofaro, A.; Hsiang, H.L.; Wheeler, A.L.; Guskjolen, A.; Niibori, Y.; Shoji, H.; et al. Hippocampal neurogenesis regulates forgetting during adulthood and infancy. Science 2014, 344, 598-602. [CrossRef]

70. Anacker, C.; Luna, V.M.; Stevens, G.S.; Millette, A.; Shores, R.; Jimenez, J.C.; Chen, B.; Hen, R. Hippocampal neurogenesis confers stress resilience by inhibiting the ventral dentate gyrus. Nature 2018, 559, 98-102. [CrossRef]

71. Sah, N.; Peterson, B.D.; Lubejko, S.T.; Vivar, C.; van Praag, H. Running reorganizes the circuitry of one-week-old adult-born hippocampal neurons. Sci. Rep. 2017, 7, 10903. [CrossRef] [PubMed]

72. Yamada, J.; Nadanaka, S.; Kitagawa, H.; Takeuchi, K.; Jinno, S. Increased Synthesis of Chondroitin Sulfate Proteoglycan Promotes Adult Hippocampal Neurogenesis in Response to Enriched Environment. J. Neurosci. 2018, 38, 8496-8513. [CrossRef] [PubMed]

73. Kempermann, G.; Kuhn, H.G.; Gage, F.H. More hippocampal neurons in adult mice living in an enriched environment. Nature 1997, 386, 493-495. [CrossRef] [PubMed]

74. Schoenfeld, T.J.; McCausland, H.C.; Morris, H.D.; Padmanaban, V.; Cameron, H.A. Stress and Loss of Adult Neurogenesis Differentially Reduce Hippocampal Volume. Biol. Psychiatry 2017, 82, 914-923. [CrossRef]

75. Mahar, I.; Bambico, F.R.; Mechawar, N.; Nobrega, J.N. Stress, serotonin, and hippocampal neurogenesis in relation to depression and antidepressant effects. Neurosci. Biobehav. Rev. 2014, 38, 173-192. [CrossRef]

76. Luo, J.; Daniels, S.B.; Lennington, J.B.; Notti, R.Q.; Conover, J.C. The aging neurogenic subventricular zone. Aging Cell 2006, 5, 139-152. [CrossRef]

77. Enwere, E.; Shingo, T.; Gregg, C.; Fujikawa, H.; Ohta, S.; Weiss, S. Aging results in reduced epidermal growth factor receptor signaling, diminished olfactory neurogenesis, and deficits in fine olfactory discrimination. $J$. Neurosci. 2004, 24, 8354-8365. [CrossRef]

78. Maslov, A.Y.; Barone, T.A.; Plunkett, R.J.; Pruitt, S.C. Neural stem cell detection, characterization, and age-related changes in the subventricular zone of mice. J. Neurosci. 2004, 24, 1726-1733. [CrossRef]

79. Tobin, M.K.; Musaraca, K.; Disouky, A.; Shetti, A.; Bheri, A.; Honer, W.G.; Kim, N.; Dawe, R.J.; Bennett, D.A.; Arfanakis, K.; et al. Human Hippocampal Neurogenesis Persists in Aged Adults and Alzheimer's Disease Patients. Cell Stem Cell 2019, 24, 974-982.e973. [CrossRef]

80. Lazarov, O.; Marr, R.A. Neurogenesis and Alzheimer's disease: At the crossroads. Exp. Neurol. 2010, 223, 267-281. [CrossRef]

81. Wang, R.; Dineley, K.T.; Sweatt, J.D.; Zheng, H. Presenilin 1 familial Alzheimer's disease mutation leads to defective associative learning and impaired adult neurogenesis. Neuroscience 2004, 126, 305-312. [CrossRef] [PubMed]

82. Wen, P.H.; Hof, P.R.; Chen, X.; Gluck, K.; Austin, G.; Younkin, S.G.; Younkin, L.H.; DeGasperi, R.; Gama Sosa, M.A.; Robakis, N.K.; et al. The presenilin-1 familial Alzheimer disease mutant P117L impairs neurogenesis in the hippocampus of adult mice. Exp. Neurol. 2004, 188, 224-237. [CrossRef] [PubMed] 
83. Choi, S.H.; Veeraraghavalu, K.; Lazarov, O.; Marler, S.; Ransohoff, R.M.; Ramirez, J.M.; Sisodia, S.S. Non-cell-autonomous effects of presenilin 1 variants on enrichment-mediated hippocampal progenitor cell proliferation and differentiation. Neuron 2008, 59, 568-580. [CrossRef] [PubMed]

84. Donovan, M.H.; Yazdani, U.; Norris, R.D.; Games, D.; German, D.C.; Eisch, A.J. Decreased adult hippocampal neurogenesis in the PDAPP mouse model of Alzheimer's disease. J. Comp. Neurol. 2006, 495, 70-83. [CrossRef]

85. Jin, K.; Peel, A.L.; Mao, X.O.; Xie, L.; Cottrell, B.A.; Henshall, D.C.; Greenberg, D.A. Increased hippocampal neurogenesis in Alzheimer's disease. Proc. Natl. Acad. Sci. USA 2004, 101, 343-347. [CrossRef]

86. Lopez-Toledano, M.A.; Shelanski, M.L. Increased neurogenesis in young transgenic mice overexpressing human APP(Sw, Ind). J. Alzheimers Dis. 2007, 12, 229-240. [CrossRef]

87. Gan, L.; Qiao, S.; Lan, X.; Chi, L.; Luo, C.; Lien, L.; Liu, Q.Y.; Liu, R. Neurogenic responses to amyloid-beta plaques in the brain of Alzheimer's disease-like transgenic (pPDGF-APPSw,Ind) mice. Neurobiol. Dis. 2008, 29, 71-80. [CrossRef]

88. Mirochnic, S.; Wolf, S.; Staufenbiel, M.; Kempermann, G. Age effects on the regulation of adult hippocampal neurogenesis by physical activity and environmental enrichment in the APP23 mouse model of Alzheimer disease. Hippocampus 2009, 19, 1008-1018. [CrossRef]

89. Ermini, F.V.; Grathwohl, S.; Radde, R.; Yamaguchi, M.; Staufenbiel, M.; Palmer, T.D.; Jucker, M. Neurogenesis and alterations of neural stem cells in mouse models of cerebral amyloidosis. Am. J. Pathol. 2008, 172, 1520-1528. [CrossRef]

90. Salkovic-Petrisic, M.; Knezovic, A.; Hoyer, S.; Riederer, P. What have we learned from the streptozotocin-induced animal model of sporadic Alzheimer's disease, about the therapeutic strategies in Alzheimer's research. J. Neural Transm. 2013, 120, 233-252. [CrossRef]

91. Sun, P.; Knezovic, A.; Parlak, M.; Cuber, J.; Karabeg, M.M.; Deckert, J.; Riederer, P.; Hua, Q.; Salkovic-Petrisic, M.; Schmitt, A.G. Long-Term Effects of Intracerebroventricular Streptozotocin Treatment on Adult Neurogenesis in the Rat Hippocampus. Curr. Alzheimer Res. 2015, 12, 772-784. [CrossRef] [PubMed]

92. Boekhoorn, K.; Joels, M.; Lucassen, P.J. Increased proliferation reflects glial and vascular-associated changes, but not neurogenesis in the presenile Alzheimer hippocampus. Neurobiol. Dis. 2006, 24, 1-14. [CrossRef] [PubMed]

93. Li, B.; Yamamori, H.; Tatebayashi, Y.; Shafit-Zagardo, B.; Tanimukai, H.; Chen, S.; Iqbal, K.; Grundke-Iqbal, I. Failure of neuronal maturation in Alzheimer disease dentate gyrus. J. Neuropathol. Exp. Neurol. 2008, 67, 78-84. [CrossRef] [PubMed]

94. Crews, L.; Adame, A.; Patrick, C.; Delaney, A.; Pham, E.; Rockenstein, E.; Hansen, L.; Masliah, E. Increased BMP6 levels in the brains of Alzheimer's disease patients and APP transgenic mice are accompanied by impaired neurogenesis. J. Neurosci. 2010, 30, 12252-12262. [CrossRef]

95. Lie, D.C.; Colamarino, S.A.; Song, H.J.; Desire, L.; Mira, H.; Consiglio, A.; Lein, E.S.; Jessberger, S.; Lansford, H.; Dearie, A.R.; et al. Wnt signalling regulates adult hippocampal neurogenesis. Nature 2005, 437, 1370-1375. [CrossRef]

96. Zhang, L.; Yang, X.; Yang, S.; Zhang, J. The Wnt/beta-catenin signaling pathway in the adult neurogenesis. Eur. J. Neurosci. 2011, 33, 1-8. [CrossRef]

97. Imayoshi, I.; Sakamoto, M.; Yamaguchi, M.; Mori, K.; Kageyama, R. Essential roles of Notch signaling in maintenance of neural stem cells in developing and adult brains. J. Neurosci. 2010, 30, 3489-3498. [CrossRef]

98. Ables, J.L.; Decarolis, N.A.; Johnson, M.A.; Rivera, P.D.; Gao, Z.; Cooper, D.C.; Radtke, F.; Hsieh, J.; Eisch, A.J. Notch1 is required for maintenance of the reservoir of adult hippocampal stem cells. J. Neurosci. 2010, 30, 10484-10492. [CrossRef]

99. Aguirre, A.; Rubio, M.E.; Gallo, V. Notch and EGFR pathway interaction regulates neural stem cell number and self-renewal. Nature 2010, 467, 323-327. [CrossRef]

100. Lai, K.; Kaspar, B.K.; Gage, F.H.; Schaffer, D.V. Sonic hedgehog regulates adult neural progenitor proliferation in vitro and in vivo. Nat. Neurosci. 2003, 6, 21-27. [CrossRef]

101. Conover, J.C.; Doetsch, F.; Garcia-Verdugo, J.M.; Gale, N.W.; Yancopoulos, G.D.; Alvarez-Buylla, A. Disruption of Eph/ephrin signaling affects migration and proliferation in the adult subventricular zone. Nat. Neurosci. 2000, 3, 1091-1097. [CrossRef] [PubMed] 
102. Chumley, M.J.; Catchpole, T.; Silvany, R.E.; Kernie, S.G.; Henkemeyer, M. EphB receptors regulate stem/progenitor cell proliferation, migration, and polarity during hippocampal neurogenesis. J. Neurosci. 2007, 27, 13481-13490. [CrossRef] [PubMed]

103. Singh, R.P.; Shiue, K.; Schomberg, D.; Zhou, F.C. Cellular epigenetic modifications of neural stem cell differentiation. Cell Transplant. 2009, 18, 1197-1211. [CrossRef] [PubMed]

104. Tsujimura, K.; Abematsu, M.; Kohyama, J.; Namihira, M.; Nakashima, K. Neuronal differentiation of neural precursor cells is promoted by the methyl-CpG-binding protein MeCP2. Exp. Neurol. 2009, 219, 104-111. [CrossRef] [PubMed]

105. Ma, D.K.; Jang, M.H.; Guo, J.U.; Kitabatake, Y.; Chang, M.L.; Pow-Anpongkul, N.; Flavell, R.A.; Lu, B.; Ming, G.L.; Song, H. Neuronal activity-induced Gadd45b promotes epigenetic DNA demethylation and adult neurogenesis. Science 2009, 323, 1074-1077. [CrossRef] [PubMed]

106. Sun, G.; Yu, R.T.; Evans, R.M.; Shi, Y. Orphan nuclear receptor TLX recruits histone deacetylases to repress transcription and regulate neural stem cell proliferation. Proc. Natl. Acad. Sci. USA 2007, 104, 15282-15287. [CrossRef]

107. Thiel, G.; Ekici, M.; Rossler, O.G. RE-1 silencing transcription factor (REST): A regulator of neuronal development and neuronal/endocrine function. Cell Tissue Res. 2015, 359, 99-109. [CrossRef]

108. Sun, C.N.; Chuang, H.C.; Wang, J.Y.; Chen, S.Y.; Cheng, Y.Y.; Lee, C.F.; Chern, Y. The A2A adenosine receptor rescues neuritogenesis impaired by p53 blockage via KIF2A, a kinesin family member. Dev. Neurobiol. 2010, 70, 604-621. [CrossRef]

109. Wittko, I.M.; Schanzer, A.; Kuzmichev, A.; Schneider, F.T.; Shibuya, M.; Raab, S.; Plate, K.H. VEGFR-1 regulates adult olfactory bulb neurogenesis and migration of neural progenitors in the rostral migratory stream in vivo. J. Neurosci. 2009, 29, 8704-8714. [CrossRef]

110. Leventhal, C.; Rafii, S.; Rafii, D.; Shahar, A.; Goldman, S.A. Endothelial trophic support of neuronal production and recruitment from the adult mammalian subependyma. Mol. Cell. Neurosci. 1999, 13, 450-464. [CrossRef]

111. Yuan, H.; Chen, R.; Wu, L.; Chen, Q.; Hu, A.; Zhang, T.; Wang, Z.; Zhu, X. The regulatory mechanism of neurogenesis by IGF-1 in adult mice. Mol. Neurobiol. 2015, 51, 512-522. [CrossRef] [PubMed]

112. Zhang, Q.; Liu, G.; Wu, Y.; Sha, H.; Zhang, P.; Jia, J. BDNF promotes EGF-induced proliferation and migration of human fetal neural stem/progenitor cells via the PI3K/Akt pathway. Molecules 2011, 16, 10146-10156. [CrossRef] [PubMed]

113. Funa, K.; Sasahara, M. The roles of PDGF in development and during neurogenesis in the normal and diseased nervous system. J. Neuroimmune Pharmacol. 2014, 9, 168-181. [CrossRef] [PubMed]

114. Palmer, T.D.; Willhoite, A.R.; Gage, F.H. Vascular niche for adult hippocampal neurogenesis. J. Comp. Neurol. 2000, 425, 479-494. [CrossRef]

115. Shen, Q.; Wang, Y.; Kokovay, E.; Lin, G.; Chuang, S.M.; Goderie, S.K.; Roysam, B.; Temple, S. Adult SVZ stem cells lie in a vascular niche: A quantitative analysis of niche cell-cell interactions. Cell Stem Cell 2008, 3, 289-300. [CrossRef]

116. Louissaint, A., Jr.; Rao, S.; Leventhal, C.; Goldman, S.A. Coordinated interaction of neurogenesis and angiogenesis in the adult songbird brain. Neuron 2002, 34, 945-960. [CrossRef]

117. Fuster-Matanzo, A.; Llorens-Martin, M.; Hernandez, F.; Avila, J. Role of neuroinflammation in adult neurogenesis and Alzheimer disease: Therapeutic approaches. Mediat. Inflamm. 2013, 2013, 260925. [CrossRef]

118. Russo, I.; Barlati, S.; Bosetti, F. Effects of neuroinflammation on the regenerative capacity of brain stem cells. J. Neurochem. 2011, 116, 947-956. [CrossRef]

119. Sierra, A.; Encinas, J.M.; Deudero, J.J.; Chancey, J.H.; Enikolopov, G.; Overstreet-Wadiche, L.S.; Tsirka, S.E.; Maletic-Savatic, M. Microglia shape adult hippocampal neurogenesis through apoptosis-coupled phagocytosis. Cell Stem Cell 2010, 7, 483-495. [CrossRef]

120. Walton, N.M.; Sutter, B.M.; Laywell, E.D.; Levkoff, L.H.; Kearns, S.M.; Marshall, G.P., 2nd; Scheffler, B.; Steindler, D.A. Microglia instruct subventricular zone neurogenesis. Glia 2006, 54, 815-825. [CrossRef]

121. Ekdahl, C.T.; Claasen, J.-H.; Bonde, S.; Kokaia, Z.; Lindvall, O. Inflammation is detrimental for neurogenesis in adult brain. Proc. Natl. Acad. Sci. USA 2003, 100, 13632-13637. [CrossRef] [PubMed]

122. Monje, M.L.; Toda, H.; Palmer, T.D. Inflammatory blockade restores adult hippocampal neurogenesis. Science 2003, 302, 1760-1765. [CrossRef] [PubMed] 
123. Belarbi, K.; Arellano, C.; Ferguson, R.; Jopson, T.; Rosi, S. Chronic neuroinflammation impacts the recruitment of adult-born neurons into behaviorally relevant hippocampal networks. Brain Behav. Immun. 2012, 26, 18-23. [CrossRef] [PubMed]

124. Islam, O.; Gong, X.; Rose-John, S.; Heese, K. Interleukin-6 and neural stem cells: More than gliogenesis. Mol. Biol. Cell 2009, 20, 188-199. [CrossRef] [PubMed]

125. Ajmone-Cat, M.A.; Cacci, E.; Ragazzoni, Y.; Minghetti, L.; Biagioni, S. Pro-gliogenic effect of IL-1alpha in the differentiation of embryonic neural precursor cells in vitro. J. Neurochem. 2010, 113, 1060-1072. [CrossRef]

126. Bachstetter, A.D.; Morganti, J.M.; Jernberg, J.; Schlunk, A.; Mitchell, S.H.; Brewster, K.W.; Hudson, C.E.; Cole, M.J.; Harrison, J.K.; Bickford, P.C.; et al. Fractalkine and CX 3 CR1 regulate hippocampal neurogenesis in adult and aged rats. Neurobiol. Aging 2011, 32, 2030-2044. [CrossRef]

127. Kiyota, T.; Ingraham, K.L.; Swan, R.J.; Jacobsen, M.T.; Andrews, S.J.; Ikezu, T. AAV serotype 2/1-mediated gene delivery of anti-inflammatory interleukin-10 enhances neurogenesis and cognitive function in APP+PS1 mice. Gene Ther. 2012, 19, 724-733. [CrossRef]

128. Fan, Q.; Gayen, M.; Singh, N.; Gao, F.; He, W.; Hu, X.; Tsai, L.H.; Yan, R. The intracellular domain of CX3CL1 regulates adult neurogenesis and Alzheimer's amyloid pathology. J. Exp. Med. 2019, 216, 1891-1903. [CrossRef]

129. Wu, Y.; Peng, H.; Cui, M.; Whitney, N.P.; Huang, Y.; Zheng, J.C. CXCL12 increases human neural progenitor cell proliferation through Akt-1/FOXO3a signaling pathway. J. Neurochem. 2009, 109, 1157-1167. [CrossRef]

130. Huang, F.; Lan, Y.; Qin, L.; Dong, H.; Shi, H.; Wu, H.; Zou, Q.; Hu, Z.; Wu, X. Astragaloside IV Promotes Adult Neurogenesis in Hippocampal Dentate Gyrus of Mouse through CXCL1/CXCR2 Signaling. Molecules 2018, 23, 2178. [CrossRef]

131. Wong, G.; Goldshmit, Y.; Turnley, A.M. Interferon-gamma but not TNF alpha promotes neuronal differentiation and neurite outgrowth of murine adult neural stem cells. Exp. Neurol. 2004, 187, 171-177. [CrossRef] [PubMed]

132. Liu, Y.P.; Lin, H.I.; Tzeng, S.F. Tumor necrosis factor-alpha and interleukin-18 modulate neuronal cell fate in embryonic neural progenitor culture. Brain Res. 2005, 1054, 152-158. [CrossRef] [PubMed]

133. Villeda, S.A.; Luo, J.; Mosher, K.I.; Zou, B.; Britschgi, M.; Bieri, G.; Stan, T.M.; Fainberg, N.; Ding, Z.; Eggel, A.; et al. The ageing systemic milieu negatively regulates neurogenesis and cognitive function. Nature 2011, 477, 90-94. [CrossRef] [PubMed]

134. Green, H.F.; Treacy, E.; Keohane, A.K.; Sullivan, A.M.; O’Keeffe, G.W.; Nolan, Y.M. A role for interleukin-1beta in determining the lineage fate of embryonic rat hippocampal neural precursor cells. Mol. Cell. Neurosci. 2012, 49, 311-321. [CrossRef] [PubMed]

135. Vallieres, L.; Campbell, I.L.; Gage, F.H.; Sawchenko, P.E. Reduced hippocampal neurogenesis in adult transgenic mice with chronic astrocytic production of interleukin-6. J. Neurosci. 2002, 22, 486-492. [CrossRef] [PubMed]

136. Gadadhar, A.; Marr, R.; Lazarov, O. Presenilin-1 regulates neural progenitor cell differentiation in the adult brain. J. Neurosci. 2011, 31, 2615-2623. [CrossRef]

137. Bonds, J.A.; Kuttner-Hirshler, Y.; Bartolotti, N.; Tobin, M.K.; Pizzi, M.; Marr, R.; Lazarov, O. Presenilin-1 Dependent Neurogenesis Regulates Hippocampal Learning and Memory. PLoS ONE 2015, 10, e0131266. [CrossRef]

138. Gakhar-Koppole, N.; Hundeshagen, P.; Mandl, C.; Weyer, S.W.; Allinquant, B.; Muller, U.; Ciccolini, F. Activity requires soluble amyloid precursor protein alpha to promote neurite outgrowth in neural stem cell-derived neurons via activation of the MAPK pathway. Eur. J. Neurosci. 2008, 28, 871-882. [CrossRef]

139. Coronel, R.; Palmer, C.; Bernabeu-Zornoza, A.; Monteagudo, M.; Rosca, A.; Zambrano, A.; Liste, I. Physiological effects of amyloid precursor protein and its derivatives on neural stem cell biology and signaling pathways involved. Neural Regen. Res. 2019, 14, 1661-1671. [CrossRef]

140. Scopa, C.; Marrocco, F.; Latina, V.; Ruggeri, F.; Corvaglia, V.; La Regina, F.; Ammassari-Teule, M.; Middei, S.; Amadoro, G.; Meli, G.; et al. Impaired adult neurogenesis is an early event in Alzheimer's disease neurodegeneration, mediated by intracellular Abeta oligomers. Cell Death Differ. 2019. [CrossRef]

141. Trazzi, S.; Mitrugno, V.M.; Valli, E.; Fuchs, C.; Rizzi, S.; Guidi, S.; Perini, G.; Bartesaghi, R.; Ciani, E. APP-dependent up-regulation of Ptch1 underlies proliferation impairment of neural precursors in Down syndrome. Hum. Mol. Genet. 2011, 20, 1560-1573. [CrossRef] [PubMed] 
142. Sarlak, G.; Htoo, H.H.; Hernandez, J.F.; Iizasa, H.; Checler, F.; Konietzko, U.; Song, W.; Vincent, B. Sox2 functionally interacts with betaAPP, the betaAPP intracellular domain and ADAM10 at a transcriptional level in human cells. Neuroscience 2016, 312, 153-164. [CrossRef] [PubMed]

143. Zhuang, J.; Wei, Q.; Lin, Z.; Zhou, C. Effects of ADAM10 deletion on Notch-1 signaling pathway and neuronal maintenance in adult mouse brain. Gene 2015, 555, 150-158. [CrossRef] [PubMed]

144. Li, Q.; Zhang, Z.; Li, Z.; Zhou, M.; Liu, B.; Pan, L.; Ma, Z.; Zheng, Y. ADAM17 is critical for multipolar exit and radial migration of neuronal intermediate progenitor cells in mice cerebral cortex. PLoS ONE 2013, 8, e65703. [CrossRef]

145. Yang, P.; Baker, K.A.; Hagg, T. A disintegrin and metalloprotease 21 (ADAM21) is associated with neurogenesis and axonal growth in developing and adult rodent CNS. J. Comp. Neurol. 2005, 490, 163-179. [CrossRef]

146. Demars, M.; Hu, Y.S.; Gadadhar, A.; Lazarov, O. Impaired neurogenesis is an early event in the etiology of familial Alzheimer's disease in transgenic mice. J. Neurosci. Res. 2010, 88, 2103-2117. [CrossRef]

147. Maqbool, M.; Mobashir, M.; Hoda, N. Pivotal role of glycogen synthase kinase-3: A therapeutic target for Alzheimer's disease. Eur. J. Med. Chem. 2016, 107, 63-81. [CrossRef]

148. Hooper, C.; Killick, R.; Lovestone, S. The GSK3 hypothesis of Alzheimer's disease. J. Neurochem. 2008, 104, 1433-1439. [CrossRef]

149. Fuster-Matanzo, A.; Llorens-Martín, M.; Sirerol-Piquer, M.S.; García-Verdugo, J.M.; Avila, J.; Hernández, F. Dual effects of increased glycogen synthase kinase- $3 \beta$ activity on adult neurogenesis. Hum. Mol. Genet. 2012, 22, 1300-1315.

150. Sirerol-Piquer, M.; Gomez-Ramos, P.; Hernandez, F.; Perez, M.; Moran, M.A.; Fuster-Matanzo, A.; Lucas, J.J.; Avila, J.; Garcia-Verdugo, J.M. GSK3beta overexpression induces neuronal death and a depletion of the neurogenic niches in the dentate gyrus. Hippocampus 2011, 21, 910-922. [CrossRef]

151. Choi, S.H.; Bylykbashi, E.; Chatila, Z.K.; Lee, S.W.; Pulli, B.; Clemenson, G.D.; Kim, E.; Rompala, A.; Oram, M.K.; Asselin, C. Combined adult neurogenesis and BDNF mimic exercise effects on cognition in an Alzheimer's mouse model. Science 2018, 361, eaan8821. [CrossRef] [PubMed]

152. Cacquevel, M.; Lebeurrier, N.; Chéenne, S.; Vivien, D. Cytokines in neuroinflammation and Alzheimer's disease. Curr. Drug Targets 2004, 5, 529-534. [CrossRef] [PubMed]

153. Mrak, R.E.; Griffin, W.S.T. Glia and their cytokines in progression of neurodegeneration. Neurobiol. Aging 2005, 26, 349-354. [CrossRef] [PubMed]

154. Halliday, G.; Robinson, S.R.; Shepherd, C.; Kril, J. Alzheimer's disease and inflammation: A review of cellular and therapeutic mechanisms. Clin. Exp. Pharmacol. Physiol. 2000, 27, 1-8. [CrossRef]

155. Stewart, C.R.; Stuart, L.M.; Wilkinson, K.; van Gils, J.M.; Deng, J.; Halle, A.; Rayner, K.J.; Boyer, L.; Zhong, R.; Frazier, W.A.; et al. CD36 ligands promote sterile inflammation through assembly of a Toll-like receptor 4 and 6 heterodimer. Nat. Immunol. 2010, 11, 155-161. [CrossRef]

156. Yu, Y.; Ye, R.D. Microglial Abeta receptors in Alzheimer's disease. Cell. Mol. Neurobiol. 2015, 35, 71-83. [CrossRef]

157. Combs, C.K.; Karlo, J.C.; Kao, S.C.; Landreth, G.E. beta-Amyloid stimulation of microglia and monocytes results in TNFalpha-dependent expression of inducible nitric oxide synthase and neuronal apoptosis. J. Neurosci. 2001, 21, 1179-1188. [CrossRef]

158. Lee, C.Y.; Landreth, G.E. The role of microglia in amyloid clearance from the AD brain. J. Neural Transm. 2010, 117, 949-960. [CrossRef]

159. Hickman, S.E.; Allison, E.K.; El Khoury, J. Microglial dysfunction and defective beta-amyloid clearance pathways in aging Alzheimer's disease mice. J. Neurosci. 2008, 28, 8354-8360. [CrossRef]

160. Kummer, M.P.; Hammerschmidt, T.; Martinez, A.; Terwel, D.; Eichele, G.; Witten, A.; Figura, S.; Stoll, M.; Schwartz, S.; Pape, H.C.; et al. Ear2 deletion causes early memory and learning deficits in APP/PS1 mice. J. Neurosci. 2014, 34, 8845-8854. [CrossRef]

161. Yeh, C.Y.; Vadhwana, B.; Verkhratsky, A.; Rodriguez, J.J. Early astrocytic atrophy in the entorhinal cortex of a triple transgenic animal model of Alzheimer's disease. ASN Neuro 2011, 3, 271-279. [CrossRef]

162. Carrero, I.; Gonzalo, M.R.; Martin, B.; Sanz-Anquela, J.M.; Arevalo-Serrano, J.; Gonzalo-Ruiz, A. Oligomers of beta-amyloid protein (Abeta1-42) induce the activation of cyclooxygenase-2 in astrocytes via an interaction with interleukin-1beta, tumour necrosis factor-alpha, and a nuclear factor kappa-B mechanism in the rat brain. Exp. Neurol. 2012, 236, 215-227. [CrossRef] 
163. Terwel, D.; Steffensen, K.R.; Verghese, P.B.; Kummer, M.P.; Gustafsson, J.A.; Holtzman, D.M.; Heneka, M.T. Critical role of astroglial apolipoprotein $\mathrm{E}$ and liver $\mathrm{X}$ receptor-alpha expression for microglial Abeta phagocytosis. J. Neurosci. 2011, 31, 7049-7059. [CrossRef]

164. Lian, H.; Litvinchuk, A.; Chiang, A.C.; Aithmitti, N.; Jankowsky, J.L.; Zheng, H. Astrocyte-Microglia Cross Talk through Complement Activation Modulates Amyloid Pathology in Mouse Models of Alzheimer's Disease. J. Neurosci. 2016, 36, 577-589. [CrossRef]

165. Hosokawa, M.; Klegeris, A.; Maguire, J.; McGeer, P.L. Expression of complement messenger RNAs and proteins by human oligodendroglial cells. Glia 2003, 42, 417-423. [CrossRef]

166. Liao, Y.F.; Wang, B.J.; Cheng, H.T.; Kuo, L.H.; Wolfe, M.S. Tumor necrosis factor-alpha, interleukin-1beta, and interferon-gamma stimulate gamma-secretase-mediated cleavage of amyloid precursor protein through a JNK-dependent MAPK pathway. J. Biol. Chem. 2004, 279, 49523-49532. [CrossRef]

167. Li, Y.; Liu, L.; Barger, S.W.; Griffin, W.S. Interleukin-1 mediates pathological effects of microglia on tau phosphorylation and on synaptophysin synthesis in cortical neurons through a p38-MAPK pathway. J. Neurosci. 2003, 23, 1605-1611. [CrossRef]

168. Ringheim, G.E.; Szczepanik, A.M.; Petko, W.; Burgher, K.L.; Zhu, S.Z.; Chao, C.C. Enhancement of beta-amyloid precursor protein transcription and expression by the soluble interleukin-6 receptor/interleukin-6 complex. Mol. Brain Res. 1998, 55, 35-44. [CrossRef]

169. Quintanilla, R.A.; Orellana, D.I.; Gonzalez-Billault, C.; Maccioni, R.B. Interleukin-6 induces Alzheimer-type phosphorylation of tau protein by deregulating the cdk5/p35 pathway. Exp. Cell Res. 2004, 295, 245-257. [CrossRef]

170. Smits, H.A.; Rijsmus, A.; van Loon, J.H.; Wat, J.W.; Verhoef, J.; Boven, L.A.; Nottet, H.S. Amyloid-beta-induced chemokine production in primary human macrophages and astrocytes. J. Neuroimmunol. 2002, 127, 160-168. [CrossRef]

171. Paolicelli, R.C.; Bolasco, G.; Pagani, F.; Maggi, L.; Scianni, M.; Panzanelli, P.; Giustetto, M.; Ferreira, T.A.; Guiducci, E.; Dumas, L.; et al. Synaptic pruning by microglia is necessary for normal brain development. Science 2011, 333, 1456-1458. [CrossRef]

172. Lee, S.; Varvel, N.H.; Konerth, M.E.; Xu, G.; Cardona, A.E.; Ransohoff, R.M.; Lamb, B.T. CX3CR1 deficiency alters microglial activation and reduces beta-amyloid deposition in two Alzheimer's disease mouse models. Am. J. Pathol. 2010, 177, 2549-2562. [CrossRef]

173. Veerhuis, R.; Nielsen, H.M.; Tenner, A.J. Complement in the brain. Mol. Immunol. 2011, 48, $1592-1603$. [CrossRef]

174. Webster, S.D.; Yang, A.J.; Margol, L.; Garzon-Rodriguez, W.; Glabe, C.G.; Tenner, A.J. Complement component C1q modulates the phagocytosis of Abeta by microglia. Exp. Neurol. 2000, 161, 127-138. [CrossRef]

175. Maier, M.; Peng, Y.; Jiang, L.; Seabrook, T.J.; Carroll, M.C.; Lemere, C.A. Complement C3 deficiency leads to accelerated amyloid beta plaque deposition and neurodegeneration and modulation of the microglia/macrophage phenotype in amyloid precursor protein transgenic mice. J. Neurosci. 2008, 28, 6333-6341. [CrossRef]

176. Lambert, J.C.; Heath, S.; Even, G.; Campion, D.; Sleegers, K.; Hiltunen, M.; Combarros, O.; Zelenika, D.; Bullido, M.J.; Tavernier, B.; et al. Genome-wide association study identifies variants at CLU and CR1 associated with Alzheimer's disease. Nat. Genet. 2009, 41, 1094-1099. [CrossRef]

177. Bassani, T.B.; Turnes, J.M.; Moura, E.L.R.; Bonato, J.M.; Coppola-Segovia, V.; Zanata, S.M.; Oliveira, R.; Vital, M. Effects of curcumin on short-term spatial and recognition memory, adult neurogenesis and neuroinflammation in a streptozotocin-induced rat model of dementia of Alzheimer's type. Behav. Brain Res. 2017, 335, 41-54. [CrossRef]

178. Bassani, T.B.; Bonato, J.M.; Machado, M.M.F.; Coppola-Segovia, V.; Moura, E.L.R.; Zanata, S.M.; Oliveira, R.; Vital, M. Decrease in Adult Neurogenesis and Neuroinflammation Are Involved in Spatial Memory Impairment in the Streptozotocin-Induced Model of Sporadic Alzheimer's Disease in Rats. Mol. Neurobiol. 2018, 55, 4280-4296. [CrossRef]

179. Mishra, S.K.; Singh, S.; Shukla, S.; Shukla, R. Intracerebroventricular streptozotocin impairs adult neurogenesis and cognitive functions via regulating neuroinflammation and insulin signaling in adult rats. Neurochem. Int. 2018, 113, 56-68. [CrossRef]

180. Ghosal, K.; Stathopoulos, A.; Pimplikar, S.W. APP intracellular domain impairs adult neurogenesis in transgenic mice by inducing neuroinflammation. PLoS ONE 2010, 5, e11866. [CrossRef] 
181. Valero, J.; Mastrella, G.; Neiva, I.; Sánchez, S.; Malva, J.O. Long-term effects of an acute and systemic administration of LPS on adult neurogenesis and spatial memory. Front. Neurosci. 2014, 8, 83. [CrossRef]

182. Stangl, D.; Thuret, S. Impact of diet on adult hippocampal neurogenesis. Genes Nutr. 2009, 4, $271-282$. [CrossRef]

183. Lee, J.; Duan, W.; Mattson, M.P. Evidence that brain-derived neurotrophic factor is required for basal neurogenesis and mediates, in part, the enhancement of neurogenesis by dietary restriction in the hippocampus of adult mice. J. Neurochem. 2002, 82, 1367-1375. [CrossRef]

184. Utsugi, C.; Miyazono, S.; Osada, K.; Sasajima, H.; Noguchi, T.; Matsuda, M.; Kashiwayanagi, M. Hard-diet feeding recovers neurogenesis in the subventricular zone and olfactory functions of mice impaired by soft-diet feeding. PLoS ONE 2014, 9, e97309. [CrossRef]

185. Kawakita, E.; Hashimoto, M.; Shido, O. Docosahexaenoic acid promotes neurogenesis in vitro and in vivo. Neuroscience 2006, 139, 991-997. [CrossRef]

186. Murphy, T.; Dias, G.P.; Thuret, S. Effects of diet on brain plasticity in animal and human studies: Mind the gap. Neural Plast. 2014, 2014, 563160. [CrossRef]

187. Joseph, J.A.; Shukitt-Hale, B.; Denisova, N.A.; Bielinski, D.; Martin, A.; McEwen, J.J.; Bickford, P.C. Reversals of age-related declines in neuronal signal transduction, cognitive, and motor behavioral deficits with blueberry, spinach, or strawberry dietary supplementation. J. Neurosci. 1999, 19, 8114-8121. [CrossRef]

188. Dong, S.; Zeng, Q.; Mitchell, E.S.; Xiu, J.; Duan, Y.; Li, C.; Tiwari, J.K.; Hu, Y.; Cao, X.; Zhao, Z. Curcumin enhances neurogenesis and cognition in aged rats: Implications for transcriptional interactions related to growth and synaptic plasticity. PLoS ONE 2012, 7, e31211. [CrossRef]

189. Morello, M.; Landel, V.; Lacassagne, E.; Baranger, K.; Annweiler, C.; Feron, F.; Millet, P. Vitamin D Improves Neurogenesis and Cognition in a Mouse Model of Alzheimer's Disease. Mol. Neurobiol. 2018, 55, 6463-6479. [CrossRef]

190. Wu, P.; Shen, Q.; Dong, S.; Xu, Z.; Tsien, J.Z.; Hu, Y. Calorie restriction ameliorates neurodegenerative phenotypes in forebrain-specific presenilin-1 and presenilin-2 double knockout mice. Neurobiol. Aging 2008, 29, 1502-1511. [CrossRef]

191. Qin, W.; Yang, T.; Ho, L.; Zhao, Z.; Wang, J.; Chen, L.; Zhao, W.; Thiyagarajan, M.; MacGrogan, D.; Rodgers, J.T.; et al. Neuronal SIRT1 activation as a novel mechanism underlying the prevention of Alzheimer disease amyloid neuropathology by calorie restriction. J. Biol. Chem. 2006, 281, 21745-21754. [CrossRef] [PubMed]

192. Codocedo, J.F.; Allard, C.; Godoy, J.A.; Varela-Nallar, L.; Inestrosa, N.C. SIRT1 regulates dendritic development in hippocampal neurons. PLoS ONE 2012, 7, e47073. [CrossRef] [PubMed]

193. Vedin, I.; Cederholm, T.; Freund-Levi, Y.; Basun, H.; Garlind, A.; Irving, G.F.; Eriksdotter-Jonhagen, M.; Wahlund, L.O.; Dahlman, I.; Palmblad, J. Effects of DHA-rich n-3 fatty acid supplementation on gene expression in blood mononuclear leukocytes: The OmegAD study. PLoS ONE 2012, 7, e35425. [CrossRef] [PubMed]

194. Tang, M.; Taghibiglou, C. The Mechanisms of Action of Curcumin in Alzheimer's Disease. J. Alzheimers Dis. 2017, 58, 1003-1016. [CrossRef]

195. Kao, T.K.; Ou, Y.C.; Raung, S.L.; Lai, C.Y.; Liao, S.L.; Chen, C.J. Inhibition of nitric oxide production by quercetin in endotoxin/cytokine-stimulated microglia. Life Sci. 2010, 86, 315-321. [CrossRef]

196. Cao, C.; Cirrito, J.R.; Lin, X.; Wang, L.; Verges, D.K.; Dickson, A.; Mamcarz, M.; Zhang, C.; Mori, T.; Arendash, G.W.; et al. Caffeine suppresses amyloid-beta levels in plasma and brain of Alzheimer's disease transgenic mice. J. Alzheimers Dis. 2009, 17, 681-697. [CrossRef]

197. Cao, C.; Wang, L.; Lin, X.; Mamcarz, M.; Zhang, C.; Bai, G.; Nong, J.; Sussman, S.; Arendash, G. Caffeine synergizes with another coffee component to increase plasma GCSF: Linkage to cognitive benefits in Alzheimer's mice. J. Alzheimers Dis. 2011, 25, 323-335. [CrossRef]

198. Maruszak, A.; Pilarski, A.; Murphy, T.; Branch, N.; Thuret, S. Hippocampal neurogenesis in Alzheimer's disease: Is there a role for dietary modulation? J. Alzheimers Dis. 2014, 38, 11-38. [CrossRef]

199. Kobayashi, Y.; Sugahara, H.; Shimada, K.; Mitsuyama, E.; Kuhara, T.; Yasuoka, A.; Kondo, T.; Abe, K.; Xiao, J.Z. Therapeutic potential of Bifidobacterium breve strain A1 for preventing cognitive impairment in Alzheimer's disease. Sci. Rep. 2017, 7, 13510. [CrossRef]

200. Distrutti, E.; O’Reilly, J.A.; McDonald, C.; Cipriani, S.; Renga, B.; Lynch, M.A.; Fiorucci, S. Modulation of intestinal microbiota by the probiotic VSL\#3 resets brain gene expression and ameliorates the age-related deficit in LTP. PLoS ONE 2014, 9, e106503. [CrossRef] 
201. Agahi, A.; Hamidi, G.A.; Daneshvar, R.; Hamdieh, M.; Soheili, M.; Alinaghipour, A.; Esmaeili Taba, S.M.; Salami, M. Does Severity of Alzheimer's Disease Contribute to Its Responsiveness to Modifying Gut Microbiota? A Double Blind Clinical Trial. Front. Neurol. 2018, 9, 662. [CrossRef] [PubMed]

202. Leblhuber, F.; Steiner, K.; Schuetz, B.; Fuchs, D.; Gostner, J.M. Probiotic Supplementation in Patients with Alzheimer's Dementia-An Explorative Intervention Study. Curr. Alzheimer Res. 2018, 15, 1106-1113. [CrossRef]

203. Giau, V.V.; Wu, S.Y.; Jamerlan, A.; An, S.S.A.; Kim, S.Y.; Hulme, J. Gut Microbiota and Their Neuroinflammatory Implications in Alzheimer's Disease. Nutrients 2018, 10, 1765. [CrossRef]

204. Hu, Y.S.; Xu, P.; Pigino, G.; Brady, S.T.; Larson, J.; Lazarov, O. Complex environment experience rescues impaired neurogenesis, enhances synaptic plasticity, and attenuates neuropathology in familial Alzheimer's disease-linked APPswe/PS1DeltaE9 mice. FASEB J. 2010, 24, 1667-1681. [CrossRef]

205. Van Praag, H.; Kempermann, G.; Gage, F.H. Running increases cell proliferation and neurogenesis in the adult mouse dentate gyrus. Nat. Neurosci. 1999, 2, 266. [CrossRef]

206. Van Praag, H.; Christie, B.R.; Sejnowski, T.J.; Gage, F.H. Running enhances neurogenesis, learning, and long-term potentiation in mice. Proc. Natl. Acad. Sci. USA 1999, 96, 13427-13431. [CrossRef]

207. Hötting, K.; Röder, B. Beneficial effects of physical exercise on neuroplasticity and cognition. Neurosci. Biobehav. Rev. 2013, 37, 2243-2257.

208. Brown, J.; Cooper-Kuhn, C.M.; Kempermann, G.; Van Praag, H.; Winkler, J.; Gage, F.H.; Kuhn, H.G. Enriched environment and physical activity stimulate hippocampal but not olfactory bulb neurogenesis. Eur. J. Neurosci. 2003, 17, 2042-2046.

209. Tapia-Rojas, C.; Aranguiz, F.; Varela-Nallar, L.; Inestrosa, N.C. Voluntary Running Attenuates Memory Loss, Decreases Neuropathological Changes and Induces Neurogenesis in a Mouse Model of A lzheimer's Disease. Brain Pathol. 2016, 26, 62-74.

210. Kim, B.-K.; Shin, M.-S.; Kim, C.-J.; Baek, S.-B.; Ko, Y.-C.; Kim, Y.-P. Treadmill exercise improves short-term memory by enhancing neurogenesis in amyloid beta-induced Alzheimer disease rats. J. Exerc. Rehabil. 2014, $10,2$.

211. Pereira, A.C.; Huddleston, D.E.; Brickman, A.M.; Sosunov, A.A.; Hen, R.; McKhann, G.M.; Sloan, R.; Gage, F.H.; Brown, T.R.; Small, S.A. An in vivo correlate of exercise-induced neurogenesis in the adult dentate gyrus. Proc. Natl. Acad. Sci. USA 2007, 104, 5638-5643. [CrossRef] [PubMed]

212. Ahlskog, J.E. Does vigorous exercise have a neuroprotective effect in Parkinson disease? Neurology 2011, 77, 288-294. [CrossRef] [PubMed]

213. Lautenschlager, N.T.; Cox, K.L.; Flicker, L.; Foster, J.K.; van Bockxmeer, F.M.; Xiao, J.; Greenop, K.R.; Almeida, O.P. Effect of physical activity on cognitive function in older adults at risk for Alzheimer disease: A randomized trial. JAMA 2008, 300, 1027-1037. [PubMed]

214. Barrientos, R.M. Voluntary exercise as an anti-neuroinflammatory therapeutic. Brain Behav. Immun. 2011, 25, 1061-1062. [CrossRef] [PubMed]

215. Leem, Y.-H.; Lee, Y.-I.; Son, H.-J.; Lee, S.-H. Chronic exercise ameliorates the neuroinflammation in mice carrying NSE/htau23. Biochem. Biophys. Res. Commun. 2011, 406, 359-365. [PubMed]

216. Wu, C.W.; Chen, Y.C.; Yu, L.; Chen, H.I.; Jen, C.J.; Huang, A.M.; Tsai, H.J.; Chang, Y.T.; Kuo, Y.M. Treadmill exercise counteracts the suppressive effects of peripheral lipopolysaccharide on hippocampal neurogenesis and learning and memory. J. Neurochem. 2007, 103, 2471-2481. [CrossRef] [PubMed]

217. Parachikova, A.; Nichol, K.; Cotman, C. Short-term exercise in aged Tg2576 mice alters neuroinflammation and improves cognition. Neurobiol. Dis. 2008, 30, 121-129. [CrossRef]

218. Nichol, K.E.; Poon, W.W.; Parachikova, A.I.; Cribbs, D.H.; Glabe, C.G.; Cotman, C.W. Exercise alters the immune profile in Tg2576 Alzheimer mice toward a response coincident with improved cognitive performance and decreased amyloid. J. Neuroinflamm. 2008, 5, 13. [CrossRef]

219. Belarbi, K.; Burnouf, S.; Fernandez-Gomez, F.-J.; Laurent, C.; Lestavel, S.; Figeac, M.; Sultan, A.; Troquier, L.; Leboucher, A.; Caillierez, R. Beneficial effects of exercise in a transgenic mouse model of Alzheimer's disease-like Tau pathology. Neurobiol. Dis. 2011, 43, 486-494. [CrossRef] 
220. Aisen, P.S. The potential of anti-inflammatory drugs for the treatment of Alzheimer's disease. Lancet Neurol. 2002, 1, 279-284. [CrossRef]

221. Aisen, P.S.; Davis, K.L.; Berg, J.D.; Schafer, K.; Campbell, K.; Thomas, R.G.; Weiner, M.F.; Farlow, M.R.; Sano, M.; Grundman, M.; et al. A randomized controlled trial of prednisone in Alzheimer's disease. Alzheimer's Disease Cooperative Study. Neurology 2000, 54, 588-593. [CrossRef] [PubMed]

(C) 2020 by the authors. Licensee MDPI, Basel, Switzerland. This article is an open access article distributed under the terms and conditions of the Creative Commons Attribution (CC BY) license (http://creativecommons.org/licenses/by/4.0/). 